\title{
SIXTEEN NEW SPECIES OF BULBOPHYLLUM SECTION POLYMERES (ORCHIDACEAE) FROM NEW GUINEA
}

\author{
JaAp J. Vermeulen ${ }^{1,4}$, André Schuiteman ${ }^{2} \&$ Eduard F. De Vogel ${ }^{3}$ \\ ${ }^{1} \mathrm{Jk}$.art and science, Lauwerbes 8, 2318 AT Leiden, The Netherlands \\ ${ }^{2}$ Orchid Herbarium, Royal Botanic Gardens, Kew Richmond, Surrey TW9 3AB, United Kingdom \\ ${ }^{3}$ Schoutenburgstraat 2, 2341 VZ Oegstgeest, The Netherlands \\ ${ }^{4}$ Author for correspondence: jk.artandscience@gmail.com
}

\begin{abstract}
Sixteen new species of Bulbophyllum section Polymeres (Orchidaceae) from New Guinea (Papua New Guinea and Papua Province of Indonesia) are described. Four informal series in this speciose section are distinguished as an aid to identification and a key for these is provided. The sixteen species belong to two series, sharing one character: new shoots arise from a node along the rhizome or from the basal node of the pseudobulb, without being fused to it any further than the node from which they arise. The first group (with ten new species: Bulbophyllum cerastes, B. dologlossum, B. ischyron, B. nannae, B. orthoraphe, B. schistopogon, $B$. stagmatoglossum, $B$. subium, $B$. teinodragma, $B$. trivenosum) comprises plants with creeping rhizomes, the second (with six new species: Bulbophyllum farciminiferum, B. gymnothema, B. lipochilum, B. nudicaule, $B$. radula, $B$. squamiplectum) comprises plants with patent rhizomes.
\end{abstract}

Key Words: Bulbophyllum section Polymeres informal series, new species, Papua New Guinea

At present, Bulbophyllum section Polymeres comprises approximately 170 (provisionally) accepted species (232 names) according to Vermeulen et al. (2014), and with a few more recently described species added. Four informal series were proposed for this section in Schuiteman et al. (2010). These are useful for a first division in a key to the species of the section but are unlikely to reflect the phylogeny of this group as the resulting series are not supported by additional characters in, for instance, the flowers. A key to these series runs as follows:

1. Sepals (partly) connate series A

1a. Sepals free 2

2. Rhizomes creeping or straggling. Roots spreading, arising near most pseudobulbs including recently developed ones series B

2a. Rhizomes (shortly) ascending, patent to stiffly or limply pendulous. Roots usually growing towards the point of attachment of the plant over or alongside the rhizome. Recently developed shoots usually without roots \section{3}

3. New shoots arising from a node along the rhizome (fig. 1a) or from the very base of the pseudobulb (fig. $1 b)$, not perforating the pseudobulb above its base 3a. New shoots emerging above the node from which they originate, perforating the pseudobulb above its base (Fig. 1c, 1d, 1e) series D

In series $\mathrm{D}$, the perforated part of the pseudobulb varies in length between species but varies little within species and is therefore of diagnostic value. In some species, the new shoots arise just above the base of the pseudobulb, in others close to the apex; compare Fig. 1c, 1d, and 1e.

While revising the New Guinea species of section Polymeres, we encountered several undescribed species. In this paper, we present the novelties in series $\mathrm{B}$ and $\mathrm{C}$ of the section.

Bulbophyllum section Polymeres (B1.) J.J.Verm. \& O'Byrne - Series B

Bulbophyllum cerastes J.J.Verm., Schuit. \& de Vogel, sp. nov. (Fig. 2)

TYPE: Indonesia, Papua Province, Vogelkop Peninsula, Ije River, central Tamrau Range, S slope of Mount Kusemum, ascent from Sudjak village, $1100 \mathrm{~m}$ alt., 8 Nov. 1961, Van Royen, Sleumer \& Schram 7803 (holotype L!). 

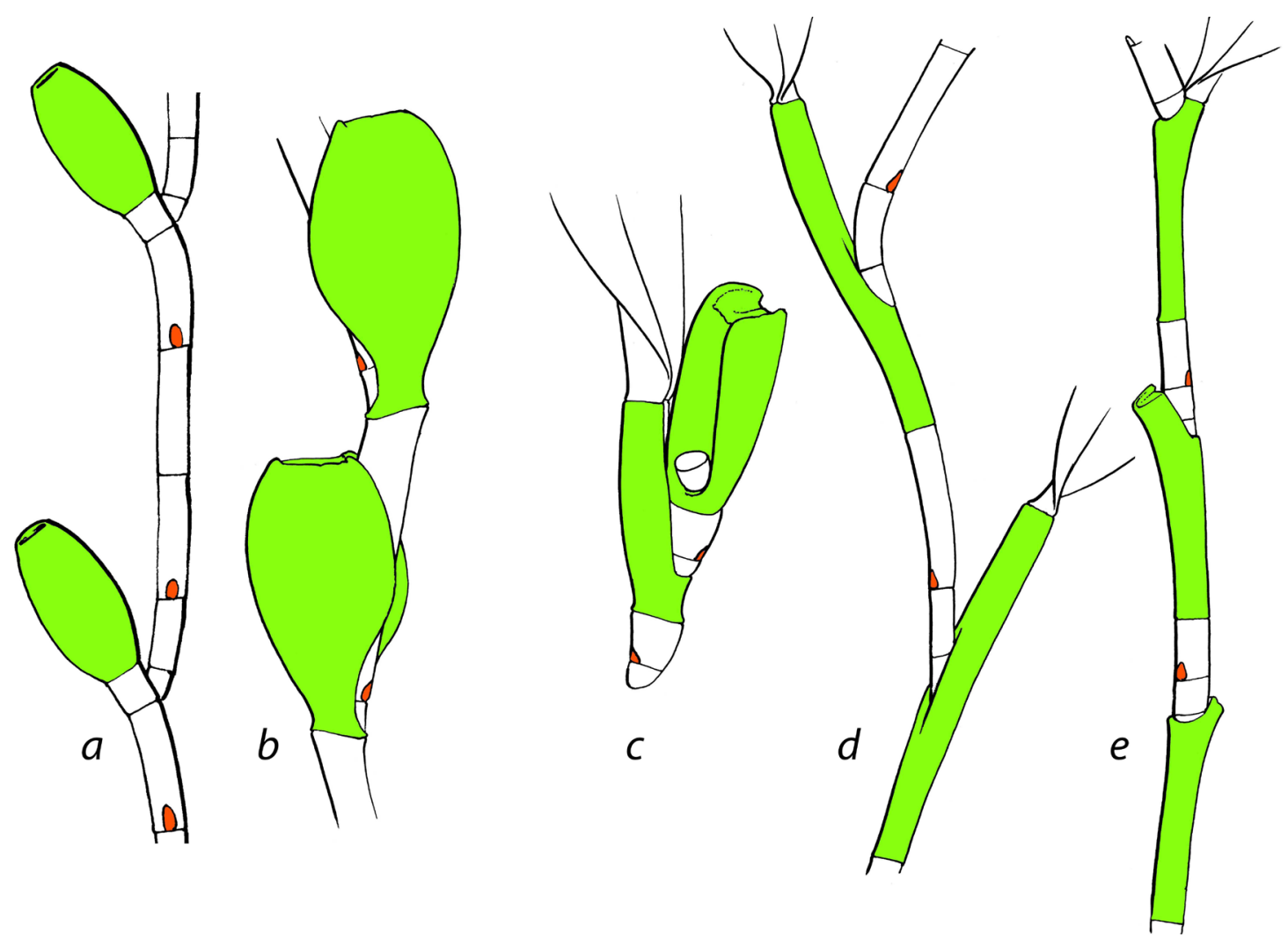

FIGURE 1. Rhizome and pseudobulb morphology in Bulbophyllum section Polymeres. a-b: New shoots emerging from a node along the rhizome (a), or the basal node of the pseudobulb (b) without being fused to the rhizome or pseudobulb any further than the node from which they originate (in b pseudobulb flanges are clasping the rhizome). c-e: New shoots emerging above the node from which they originate, because they are fused to or perforating the pseudobulb along part of the length of the latter. Rhizome sections are white, pseudobulbs green and flower buds red. Drawn by C J.J. Vermeulen.

Diagnosis. Within section Polymeres uniquely identified by the distinct, retrorse horns formed by the lateral lobes of the lip. It shares this character with Bulbophyllum trutiniferum J.J.Verm., Schuit. \& de Vogel, a species intermediate between section Brachypus and section Polymeres, but it differs from that species by the free (versus proximally adherent) sepals and the wide (ratio length/width ca. 1.5, versus 4-5), distally papillose (versus glabrous) petals.

Medium-sized epiphyte with creeping rhizomes and spreading roots. Rhizome ca. $5 \mathrm{~mm}$ diam., sections between pseudobulbs $0.5-1.0 \mathrm{~cm}$ long, arising from the basal node of the pseudobulb; rhizome scales thin, little persistent. Pseudobulbs distinct, ovoid, 1.7-3.5 $\times$ $0.7-1.2 \mathrm{~cm}$, hardly angular. Leaf: petiole $16-20 \mathrm{~mm}$ long; blade elliptic to obovate, $10.5-16.0 \times 2.5-4.1 \mathrm{~cm}$, ratio length/width 3.4-5.2; acuminate. Inflorescences few to many together, $3.5-4.5 \mathrm{~cm}$ long, 1 -flowered. Peduncle $0.8-1.9 \mathrm{~cm}$ long, scales ca. 3. Floral bracts 4.0-5.2 mm long. Flowers: pedicel plus ovary 1.5-1.6 $\mathrm{cm}$ long, basal node ca. $4.2 \mathrm{~mm}$ above the floral bract attachment. Median sepal free, recurved, elliptic, ca. $9.0 \times 4.0 \mathrm{~mm}$, ratio length/width $2.2-2.3$; acute, margins entire; glabrous, 5-veined. Lateral sepals as the median, but elliptic-ovate, ca. $9.8 \times 5.8 \mathrm{~mm}$, ratio length/width 1.6-1.7. Petals porrect, obovate, ca. 3.0 $\times 2.0 \mathrm{~mm}$, ratio length/width ca. 1.5 ; obtuse, margins approx. entire, papillose distally, adaxial surface papillose distally; 1-veined. Lip recurved approx. halfway its length, 3-lobed, elliptic-obovate in outline with projecting, retrorse, distally slightly downwards falcate, narrowly triangular, obtuse, glabrous, thin lateral lobes attached to the median lobe slightly below half-way 

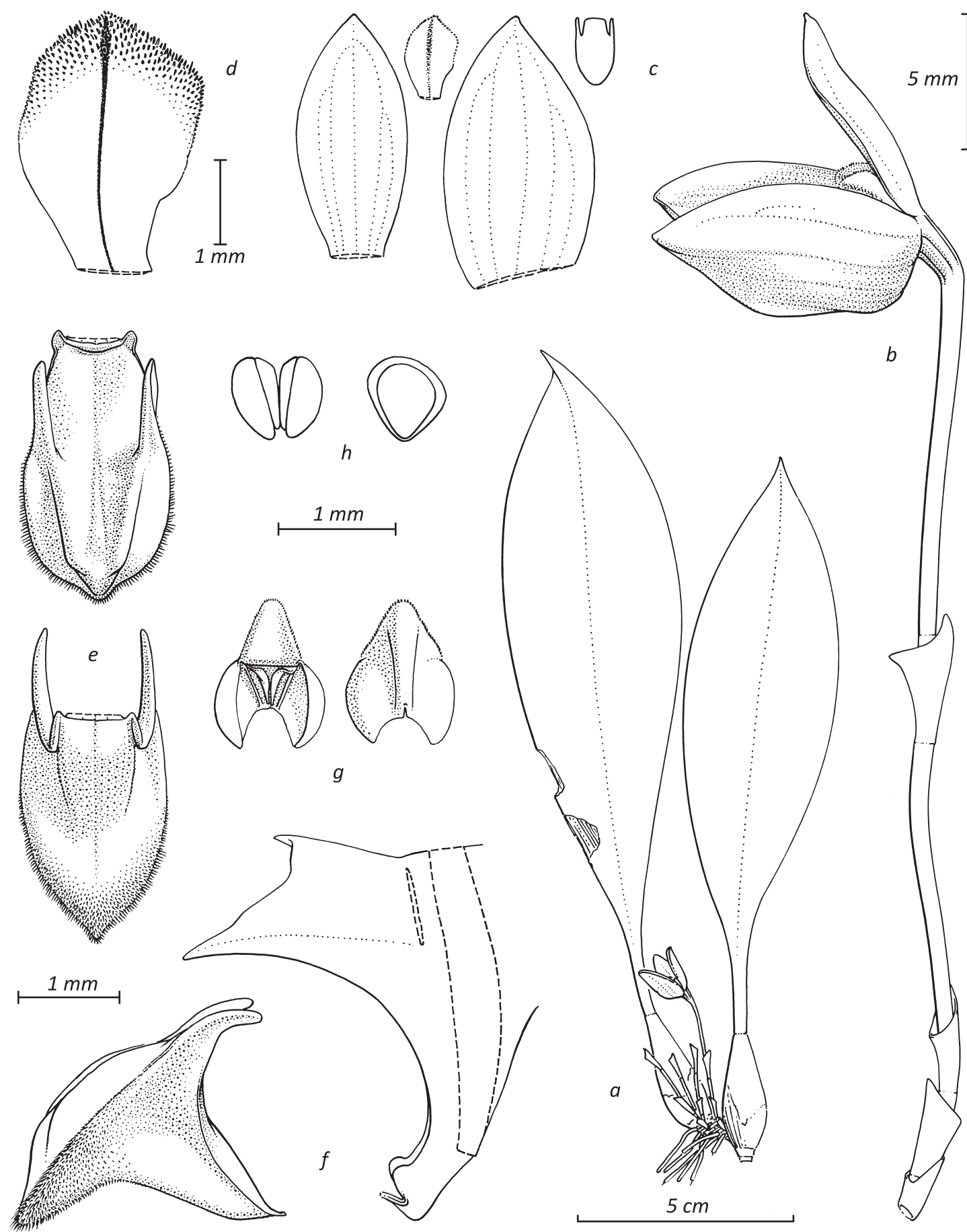

g
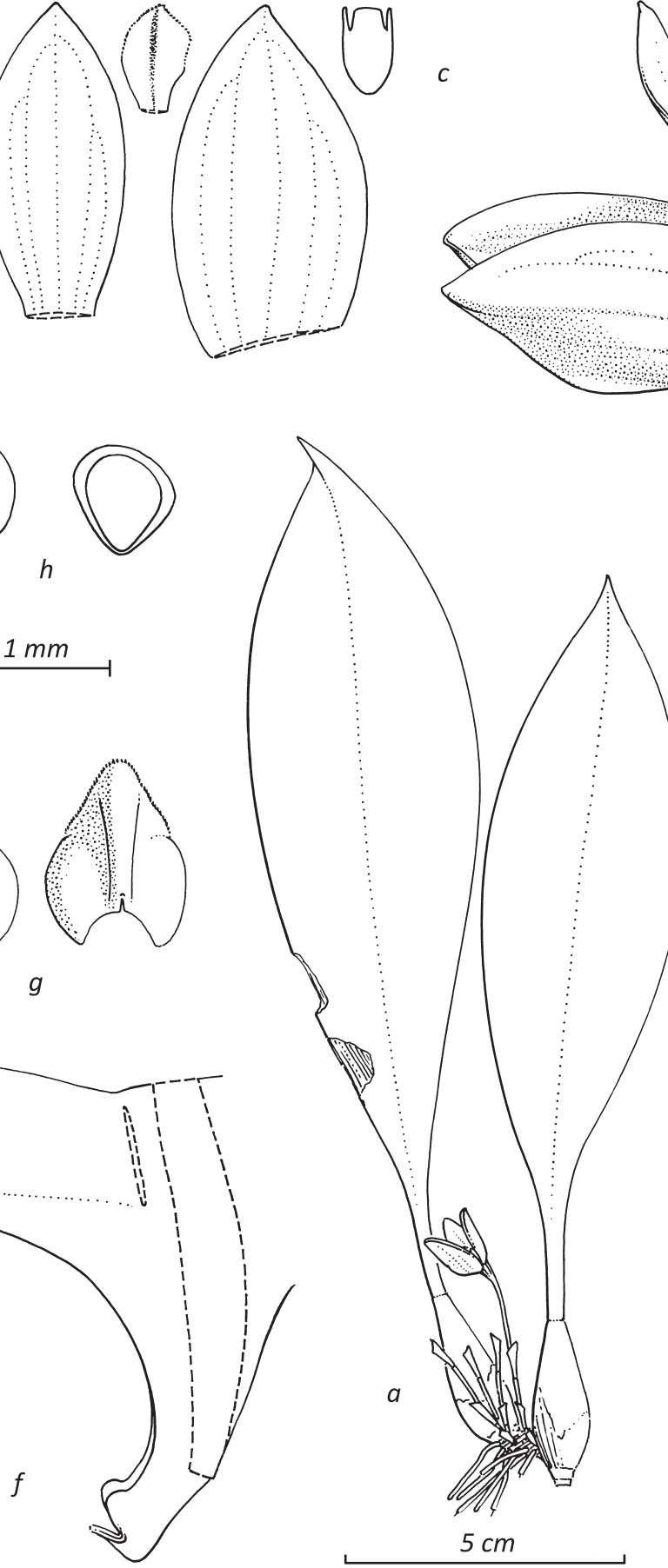

Figure 2. Bulbophyllum cerastes J.J.Verm., Schuit. \& de Vogel. a. Habit. b. Inflorescence. c. Flower analysis, from left to right: median sepal, petal, lateral sepal, lip. d. Petal. e. Lip, above: adaxial side, below: abaxial side. f. Column and lip, lateral view. g. Anther, left: adaxial side, right: abaxial side. h. Pollinia, left: two pairs, right: one pair. Drawn from Van Royen, Sleumer \& Schram 7803 by C J.J. Vermeulen, from herbarium material. 
its length; median lobe, ca. $2.6 \times 1.6 \mathrm{~mm}$, ratio length/ width 1.6-1.7 (without spreading); acute-acuminate, margins entire, ciliate beyond the attachment of the lateral lobes; thick; adaxially approx. flat proximally, distally with two rounded ridges which start close to the margins just in front of the lateral lobe attachment, then converge, meet and continue as a single median ridge to near the apex of the lip, adaxial surface glabrous; abaxially convex and glabrous proximally, slightly convex distally and increasingly hirsute towards the margins. Column including stelidia ca. 2.6 $\mathrm{mm}$ long, stigma obovate, proximally with a thickened edge which does not protrude from the lower margins of the column when the latter is viewed laterally, foot slightly widened, with small, patent, obtuse lateral teeth. Stelidia straight, narrowly triangular, ca. $1.1 \mathrm{~mm}$ long, acute. Pollinia 4 , the inner more than half as long as the outer.

Colours: flowers white.

Eтymology: kerastes (Greek) = with horns, referring to the lateral lobes of the lip.

Habitat AND ECOlogy: epiphyte on dead tree in forest. Elevation $1100 \mathrm{~m}$.

Bulbophyllum dologlossum J.J.Verm., Schuit. \& de Vogel, sp. nov. (Fig. 3)

TYPE: Papua New Guinea, Enga Province, Laiagam area, 2700-3100 m alt., Jan. 1983, Reeve 864 (holotype L!; isotypes CANB, E, LAE!, K!, NSW).

Diagnosis. Identified within series $B$ by the presence of four ridges (two long and two short) near the base of the lip, combined with the large size of the flowers and the clustered growth. Most similar is Bulbophyllum ischyron which, apart from having only two ridges on the lip, differs by having acute (versus long-acuminate) sepals and 4-veined (versus 1-veined) petals.

Medium-sized epiphyte with creeping rhizomes and spreading roots. Rhizome $4.5-7.0 \mathrm{~mm}$ diam., sections between pseudobulbs $0.9-2.2 \mathrm{~cm}$ long, arising from the basal node of the pseudobulb; rhizome scales thick, weathering to woolly fibres, persistent. Pseudobulbs distinct, ovoid-cylindrical, 2.5-7.0 $\times$ $0.8-1.2 \mathrm{~cm}$, hardly angular. Leaf: petiole $12-22 \mathrm{~mm}$ long; blade elliptic(-oblong) to obovate(-oblong), $6.2-13.5 \times 0.7-1.2 \mathrm{~cm}$, ratio length/width 8.8-12.2; obtuse. Inflorescences single or few together, 23-34 $\mathrm{cm}$ long, 1-flowered. Peduncle 13-22 cm long, scales ca. 4. Floral bracts $9.0-12.0 \mathrm{~mm}$ long. Flowers: pedicel plus ovary $3.0-4.8 \mathrm{~cm}$ long, basal node $7.0-9.0$ $\mathrm{mm}$ above the floral bract attachment. Median sepal free, recurved, ovate, ca. $75.0 \times 8.0 \mathrm{~mm}$, ratio length/ width 9.3-9.4; long-acuminate, margins slightly and minutely erose; glabrous; 3-veined. Lateral sepals as the median. Petals porrect, ovate, ca. $9.6 \times 7.0 \mathrm{~mm}$, ratio length/width ca. 1.4; acute, margins minutely erose, ciliolate, surface glabrous; 1-veined. Lip approx. straight, oblong, slightly narrowed near the base and slightly beyond half-way its length, ca. $13.8 \times 2.6$ $\mathrm{mm}$, ratio length/width ca. 5.3 (without spreading); obtuse, margins entire, approx. densely hirsute near the base, glabrous elsewhere; thick; adaxially with two converging ridges proximally which almost meet with a narrow median slit in between and then continue up to ca. $2 / 5$ of the length of the lip, and which, close to the base, have two shorter, converging ridges in between, adaxial surface slightly convex, proximally with two densely hirsute patches near the margins, elsewhere glabrous; abaxially with a deep median furrow, convex and densely hirsute proximally, slightly concave and glabrous elsewhere. Column including stelidia ca. $4 \mathrm{~mm}$ long, stigma narrowly obovate, proximally slightly protruding from the column face, foot distinctly widened, with patent, obtuse lateral teeth. Stelidia sigmoid, narrowly triangular, subulate distally, ca. $2.5 \mathrm{~mm}$ long, acute. Pollinia 4.

CoLours: sepals bright golden yellow. Distal half of lip brown, but apex and proximal half yellow. Part of column-foot purplish.

ETymology: doloon (Greek) = dagger, glossa (Greek) $=$ tongue, referring to the lip shape.

HABITAT AND ECOLOGY: common epiphyte forming large clumps. Elevation 2700-3100 m.

Bulbophyllum ischyron J.J.Verm., Schuit. \& de Vogel, sp. nov. (Fig. 4)

TYPE: Indonesia, Papua Province, Damarga Lakes, 2500-4000 m alt., Jan. 1994, Wickenden 36 (holotype E!).

Diagnosis. Most similar to Bulbophyllum dologlossum, differs by the acute sepals, the 4-veined (versus 


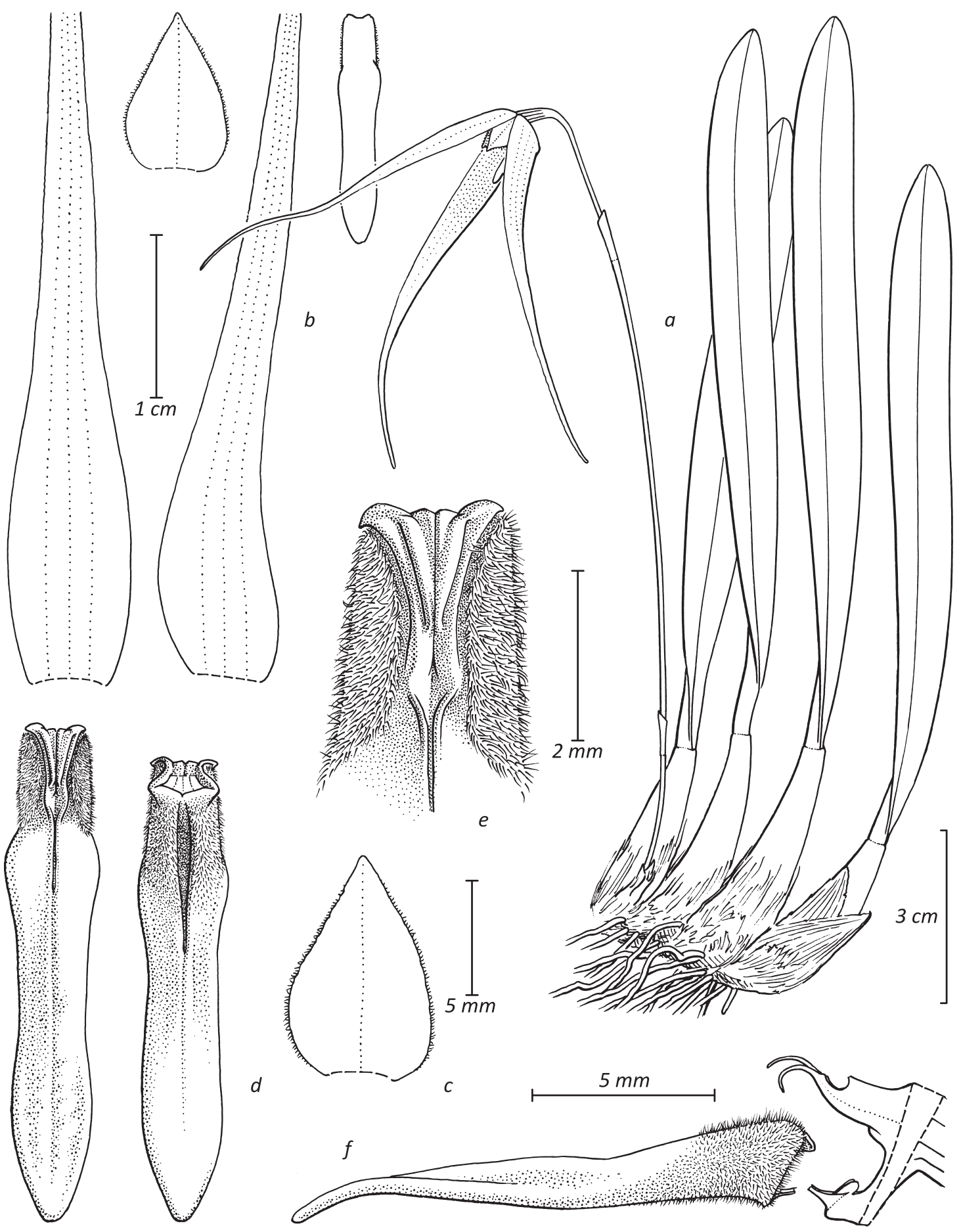

FIgURE 3. Bulbophyllum dologlossum J.J.Verm., Schuit. \& de Vogel. a. Habit. b. Flower analysis, from left to right: median sepal, petal, lateral sepal, lip. c. Petal. d. Lip, left: adaxial side, right: abaxial side. e. Lip detail. f. Column and lip, lateral view. Drawn from Reeve 864 by (C) J.J. Vermeulen, from herbarium material. 

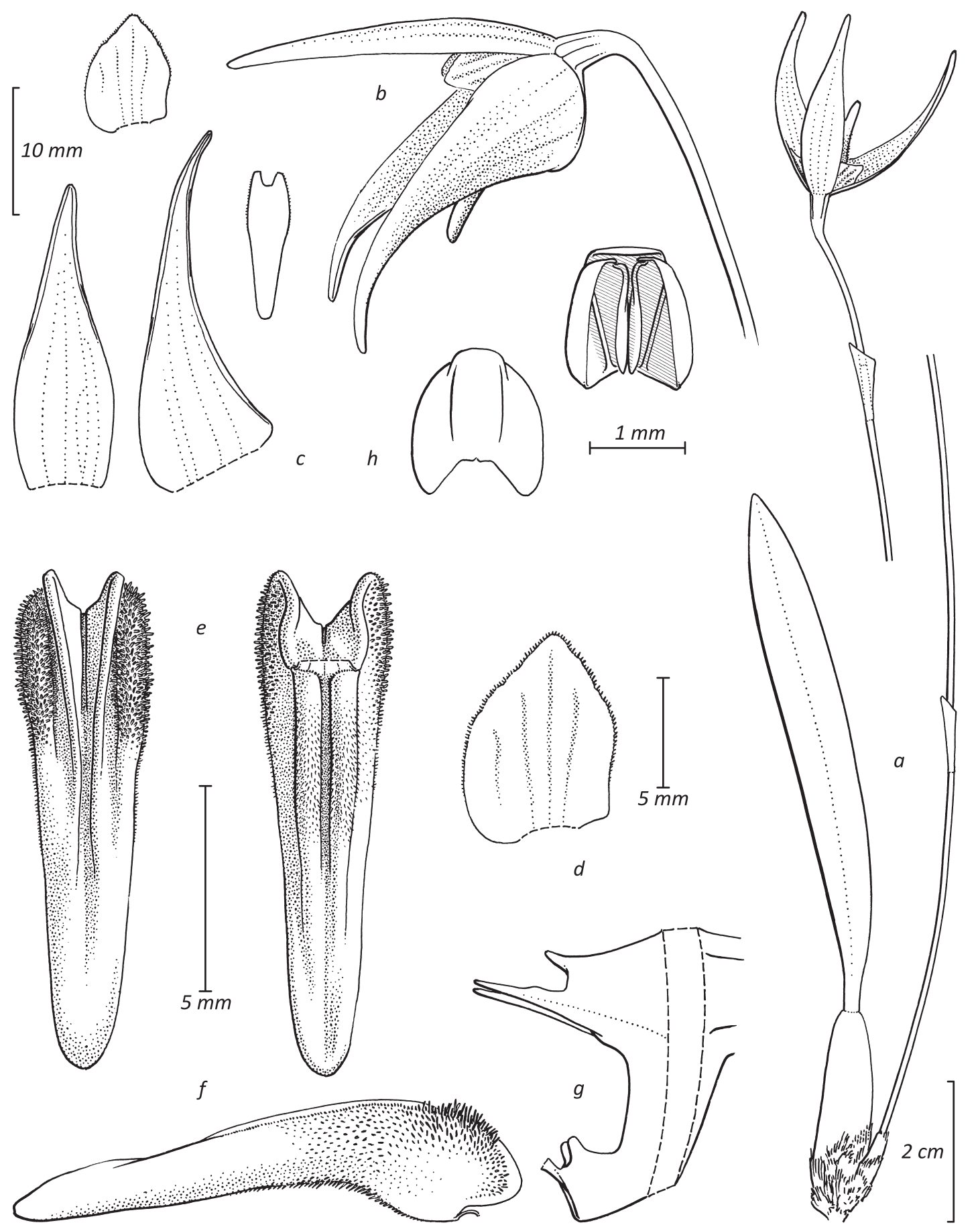
1-veined) petals, the ovate-oblong lip, gradually tapering without narrowed parts towards the apex, with only 2 (versus 4 ) ridges on the adaxial side, and the straight stelidia.

Rather small epiphyte with creeping rhizomes and spreading roots. Rhizome ca. $4 \mathrm{~mm}$ diam., sections between pseudobulbs arising from the basal node of the pseudobulb; rhizome scales thick, weathering to woolly fibres, persistent. Pseudobulbs distinct, ovoidcylindrical, ca. $2.5 \times 0.9 \mathrm{~cm}$, hardly angular. Leaf: petiole ca. $12 \mathrm{~mm}$ long; blade thick, obovate-oblong, ca. $6.4 \times 0.7 \mathrm{~cm}$, ratio length/width 9.1-9.2; subacute. Inflorescences single or few together, ca. $24 \mathrm{~cm}$ long, 1-flowered. Peduncle ca. $17 \mathrm{~cm}$ long. Floral bracts 11-12 mm long. Flowers: pedicel plus ovary ca. 4 $\mathrm{cm}$ long, basal node ca. $9 \mathrm{~mm}$ above the floral bract attachment. Median sepal free, recurved, ovate, ca. 24.0 $\times 9.0 \mathrm{~mm}$, ratio length/width 2.6-2.7; acute, margins entire; minutely papillose; 3(-4)-veined. Lateral sepals as the median but triangular, $28.0-11.5 \mathrm{~mm}$, margins glabrous. Petals porrect, ovate-oblong, ca. $10.0 \times 7.0$ $\mathrm{mm}$, ratio length/width 1.4-1.5; obtuse, margins slightly erose, ciliolate, surface glabrous; 4-veined. Lip slightly recurved near the base, ovate-oblong, ca. $12.0 \times 4.0 \mathrm{~mm}$, ratio length/width ca. 3 (without spreading); obtuse, margins approx. entire, densely hirsute towards the base, glabrous towards the apex; thick; adaxially with two slightly converging ridges, rather close together and with a rather narrow furrow in between, which continue up to ca. $3 / 5$ of the length of the lip, where they grade into the convex lip surface, adaxial surface unevenly papillose-hirsute towards the margins in the basal half of the lip, glabrous elsewhere; abaxially distinctly convex, deeply furrowed and unevenly papillose-hirsute proximally, slightly concave and glabrous distally. Column including stelidia ca. $5 \mathrm{~mm}$ long, stigma narrowly obverse-triangular, proximally not protruding from the column face, foot distinctly widened, with patent, obtuse lateral teeth. Stelidia straight, narrowly triangular, ca. $2.6 \mathrm{~mm}$ long, acute. Pollinia 4.

CoLours: flowers 'pale'.

Etymology: ischuros (Greek) = sturdy, referring to the thick leaf blade.

HABItAT AND ECOLOGY: large plant growing in shrub. Elevation 2500-4000 m.
Bulbophyllum nannae J.J.Verm., Schuit. \& de Vogel, sp. nov. (Fig. 5, 18B)

TYPE: Papua New Guinea, Milne Bay Province, Bonenau, 1300-1400 m alt., Jongejan cult. 1408 (holotype L!, spirit material).

Diagnosis. Most similar to Bulbophyllum neoguineense J.J. Sm., differs by the wider petals (ratio length/width 1.7-1.9, versus ca. 3.6) and by the base of the stigma which does not protrude from the face of the column.

Rather small epiphyte with creeping rhizomes and spreading roots. Rhizome $2.0-2.5 \mathrm{~mm}$ diam., sections between pseudobulbs $0.8-1.7 \mathrm{~cm}$ long, arising from the basal node of the pseudobulb; rhizome scales thin, little persistent. Pseudobulbs distinct, ellipsoid to ovoid, 1.1$2.0 \times 0.4-0.5 \mathrm{~cm}$, hardly angular. Leaf: petiole $0.4-0.6$ $\mathrm{mm}$ long; blade elliptic to ovate, $3.6-4.5 \times 0.8-1.2 \mathrm{~cm}$, ratio length/width 3.7-4.5; acute. Inflorescences single or a few together, ca. $8 \mathrm{~cm}$ long, 1-flowered. Peduncle ca. $5 \mathrm{~cm}$ long, scales ca. 4 . Floral bracts ca. $4 \mathrm{~mm}$ long. Flowers: pedicel plus ovary ca. $20 \mathrm{~mm}$ long, basal node ca. $1 \mathrm{~mm}$ above the floral bract attachment. Median sepal free, recurved, ovate, $8.0-9.5 \times 2.8-3.0 \mathrm{~mm}$, ratio length/width 2.6-3.4; acute, margins entire, minutely papillose, surface glabrous; 5-veined. Lateral sepals as the median but spreading, ovate-triangular, 8.0-11.0 × 3.2-3.4 mm, ratio length/width 2.5-3.3, margins glabrous. Petals porrect, rhombiform, 3.7-4.0 × 2.1$2.2 \mathrm{~mm}$, ratio length/width 1.7-1.9; obtuse, margins approx. entire, finely papillose, surface finely papillose distally; 1-veined. Lip slightly recurved, ovate, 6.4 $6.7 \times$ ca. $2.0 \mathrm{~mm}$, ratio length/width 3.2-3.4 (without spreading); rounded, margins entire, minutely papillose proximally, glabrous distally; thick and soft; adaxially concave in the proximal $1 / 3-1 / 2$, this cavity bordered by two slightly converging ridges distally gradually merging into the convex distal part of the lip, adaxial surface glabrous; abaxially with a median furrow which is deepest in the proximal, otherwise convex half, distal half somewhat concave, abaxial surface minutely papillose proximally. Column including stelidia 2.6$3.0 \mathrm{~mm}$ long, stigma narrowly obovate, proximally not protruding from the column face, foot distally widened, with spreading, rounded lateral teeth. Stelidia somewhat sigmoid, narrowly triangular, distally subulate, ca. 1.7 $\mathrm{mm}$ long, acute. Pollinia 4, the inner more than half as long as the outer.

LANKESTERIANA 20(3). 2020. (C) Universidad de Costa Rica, 2020. 

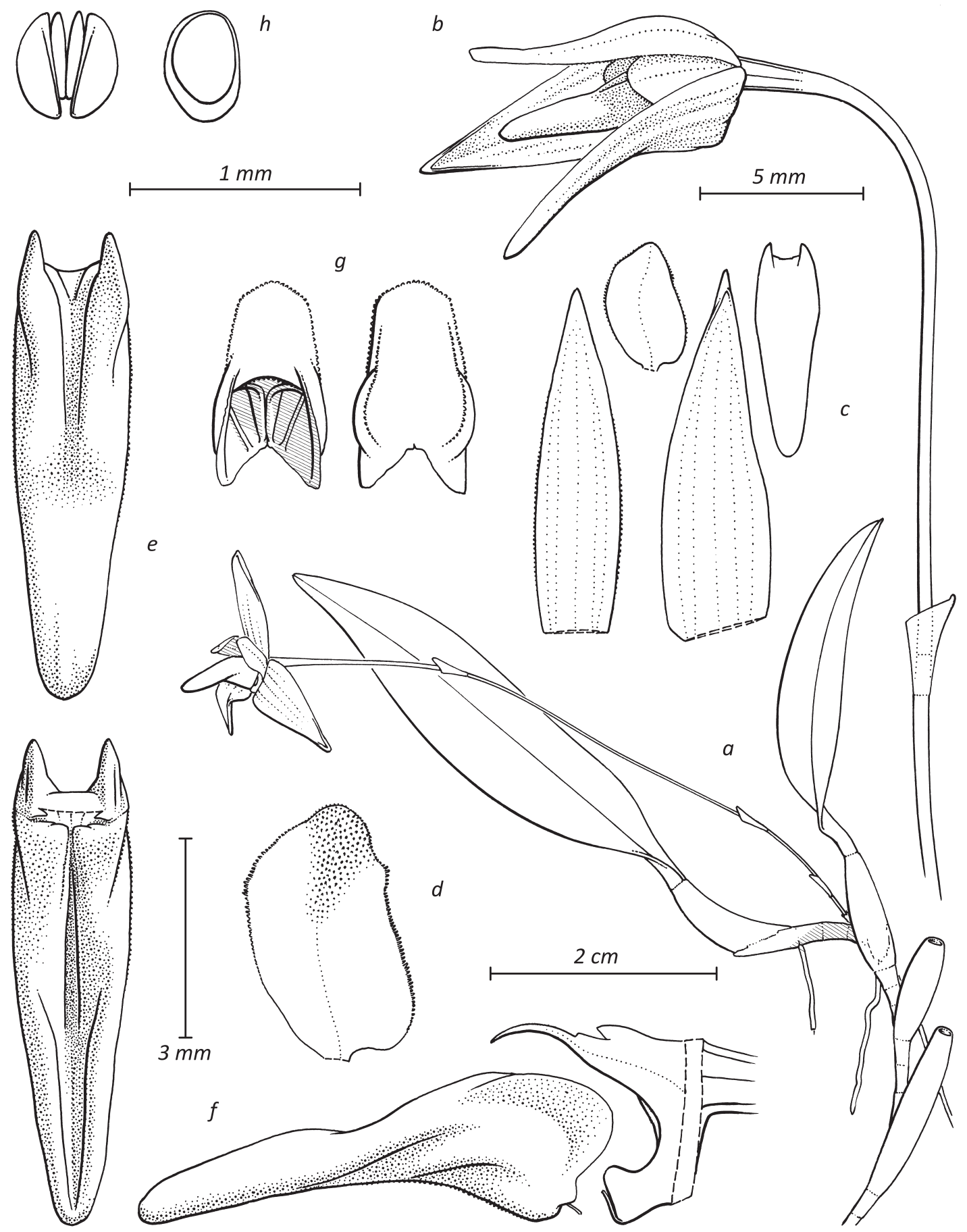

FiguRe 5. Bulbophyllum nannae J.J.Verm., Schuit. \& de Vogel. a. Habit. b. Flower. c. Flower analysis, from left to right: median sepal, petal, lateral sepal, lip. d. Petal. e. Lip, above: adaxial side, below: abaxial side. f. Column and lip, lateral view. g. Anther, left: adaxial side, right: abaxial side. h. Pollinia, left: two pairs, right: one pair. Drawn from Jongejan cult. 1408 by $\mathcal{C}$ J.J. Vermeulen, from spirit material. 
CoLours: sepals yellow-green, pale yellow along the margins, veins dark red. Petals white, yellow-green in centre, with large dark red blotches. Lip yellow, suffused brown at apex and abaxially near the base. distally and urple, white towards the edges. Petals white. Lip purple, apex green, papillae pale purple, the larger white. Column yellow.

Etymology: named after Nanna Høeg, youngest daughter of the first author, at the occasion of her 20st birthday.

Habitat AND ECOlogy: epiphyte low on tree trunk. Elevation 1300-1400 m.

Bulbophyllum orthoraphe J.J.Verm., Schuit. \& de Vogel, sp. nov. (Fig. 6)

TYPE: Papua New Guinea, Enga Province, Kandep Range, Mt. Leyan near Laiagam, ca. $3000 \mathrm{~m}$ alt., Jongejan cult. 765 (holotype L!, spirit material).

DiAGNOSIs. Shares the clustered growth, combined with a distally not attenuated lip without sharply outlined patches of papillae or hairs with Bulbophyllum dischorense Schltr. and B. muriceum Schltr., from which it differs by the oblong (versus triangular) petals and by the straight (versus sigmoid) stelidia; with $B$. meliphagirostrum Van Royen, from which it differs by the wider lip (ratio length/width 2.2-3.4, without spreading, versus 5-8) and by the shorter petals (2.2$3.2 \mathrm{~mm}$ long versus $4-5 \mathrm{~mm}$ long).

Small epiphyte with creeping rhizomes and spreading roots. Rhizome 1.0-2.0 mm diam., sections between pseudobulbs $0.1-0.5 \mathrm{~cm}$ long, arising from the basal node of the pseudobulb; rhizome scales thin, little persistent. Pseudobulbs distinct, ellipsoid to ovoid, $0.6-1.2 \times 0.1-0.5 \mathrm{~cm}$, hardly angular. Leaf: petiole $0.1-0.3 \mathrm{~mm}$ long; blade elliptic to obovate, $1.2-2.5 \times 0.4-0.6 \mathrm{~cm}$, ratio length/width $2.6-6.4$; subacute. Inflorescences single or a few together, 4.9$6.3 \mathrm{~cm}$ long, 1-flowered. Peduncle $3.0-40 \mathrm{~cm}$ long, scales 3-4. Floral bracts $2.5-5.0 \mathrm{~mm}$ long. Flowers: pedicel plus ovary 7-10 mm long, basal node 1.5-2.0 $\mathrm{mm}$ above the floral bract attachment. Median sepal free, recurved, (ovate-)triangular, 9.5-13.0 × 1.5-2.5 $\mathrm{mm}$, ratio length/width 4.8-6.4; acute(-acuminate), margins entire, ciliolate, surface glabrous; 3-veined. Lateral sepals as the median but triangular, 12.0-15.0 $\times$
1.8-2.7 mm, ratio length/width 4.8-6.7, upper margin glabrous. Petals porrect, oblong to (ob-)ovate, 2.2-3.2 $\times 0.8-1.4 \mathrm{~mm}$, ratio length/width $2.0-3.0$; obtuse to acute-acuminate, margins entire, ciliolate, surface glabrous; 1-2-veined. Lip approx. porrect, ovate, 3.7$4.3 \times 1.1-1.9 \mathrm{~mm}$, ratio length/width 2.2-3.4 (without spreading); rounded, margins entire, approx. glabrous to finely papillose in the basal half (but glabrous close to the base); thick and soft; adaxially concave in the proximal $2 / 5-1 / 2$, increasingly convex distally, adaxial surface with two vaguely outlined (minutely) papillose patches towards the margins in the basal half, otherwise glabrous; abaxially with a median furrow along its entire length, otherwise convex, surface minutely papillose proximally. Column including stelidia 1.5-1.6 $\mathrm{mm}$ long, stigma wide-obovate, proximally not protruding from the column face, foot distally widened, with spreading, rounded lateral teeth. Stelidia porrect, narrowly triangular, $0.4-0.6 \mathrm{~mm}$ long, acute. Pollinia 4, the inner more than half as long as the outer.

CoLours: flowers red-purple.

EтYMology: orthos $($ Greek) = straight, raphe $($ Greek $)$ $=$ needle, referring to the straight stelidia.

Habitat and ecology: epiphyte in moss forest. Elevation ca. $3000 \mathrm{~m}$.

Bulbophyllum schistopogon J.J.Verm., Schuit. \& de Vogel, sp. nov. (Fig. 7)

TYPE: Papua New Guinea, Southern Highlands Province, Ialibu District, Mount Giluwe, southern slopes, 2400 m alt., Apr. 1980 or Jan. 1983, Reeve 1016 (holotype L! 1495886; isotypes CANB, E!, K!, LAE!, NSW).

Diagnosis. Shares the distribution of hairs on the adaxial side of the lip with Bulbophyllum subium (see below), Bulbophyllum galliaheneum Van Royen, and with $B$. odontopetalum Schltr., it differs by the much longer, sigmoid stelidia, and the acute (versus longacuminate) sepals. In general shape it is similar to $B$. dischorense Schltr. and B. dschischungarense Schltr., it differs by the presence of hairy patches on the adaxial side of the lip.

Rather small epiphyte with creeping rhizomes and spreading roots. Rhizome $1.8-2.5 \mathrm{~mm}$ diam., sections 


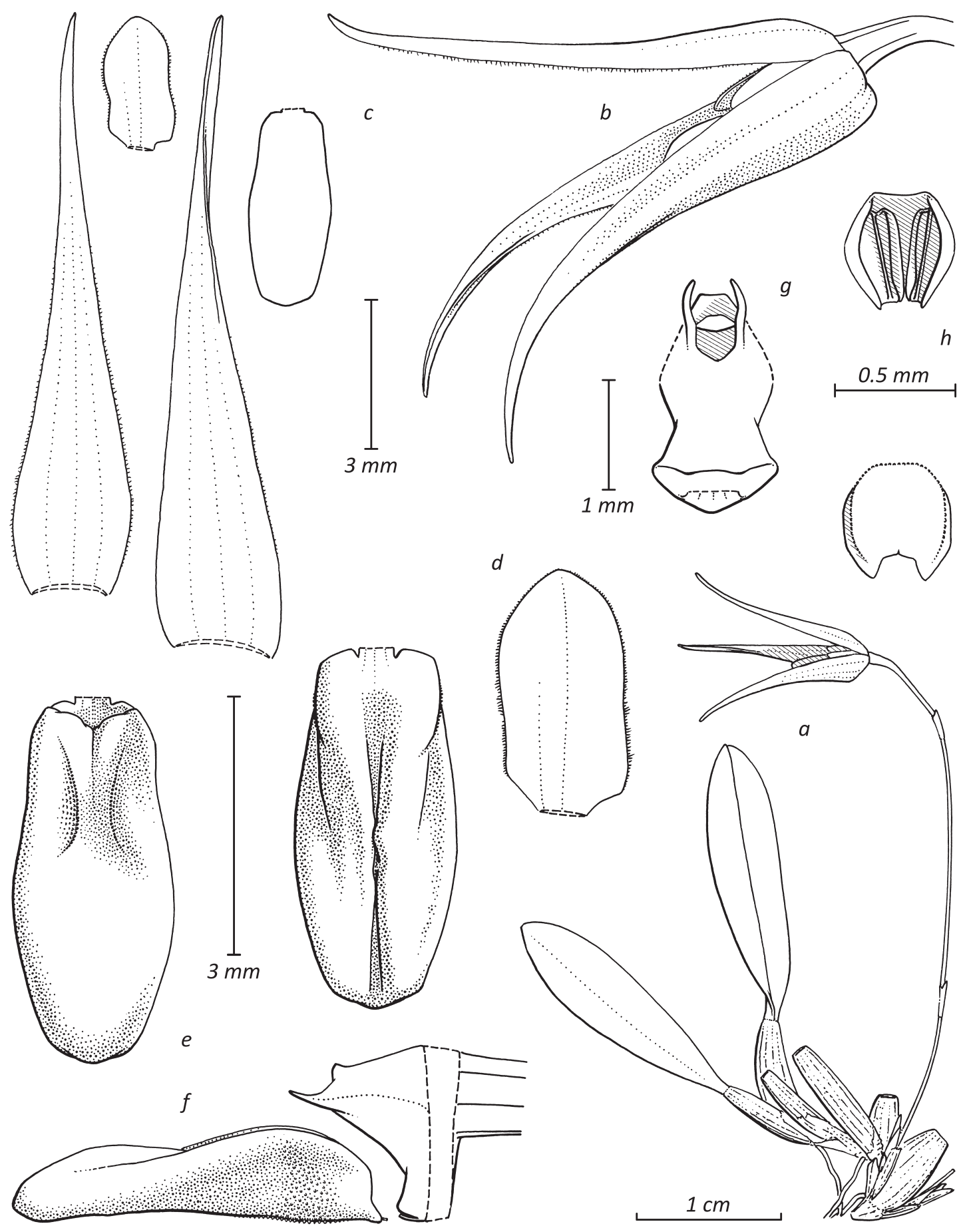

FiguRe 6. Bulbophyllum orthoraphe J.J.Verm., Schuit. \& de Vogel. a. Habit. b. Flower. c. Flower analysis, from left to right: median sepal, petal, lateral sepal, lip. d. Petal. e. Lip, left: adaxial side, right: abaxial side. f. Column and lip, lateral view. g. Column, frontal view. h. Anther, above: adaxial side, below: abaxial side. Drawn from Jongejan cult. 765 by (C) J.J. Vermeulen, from spirit material. 

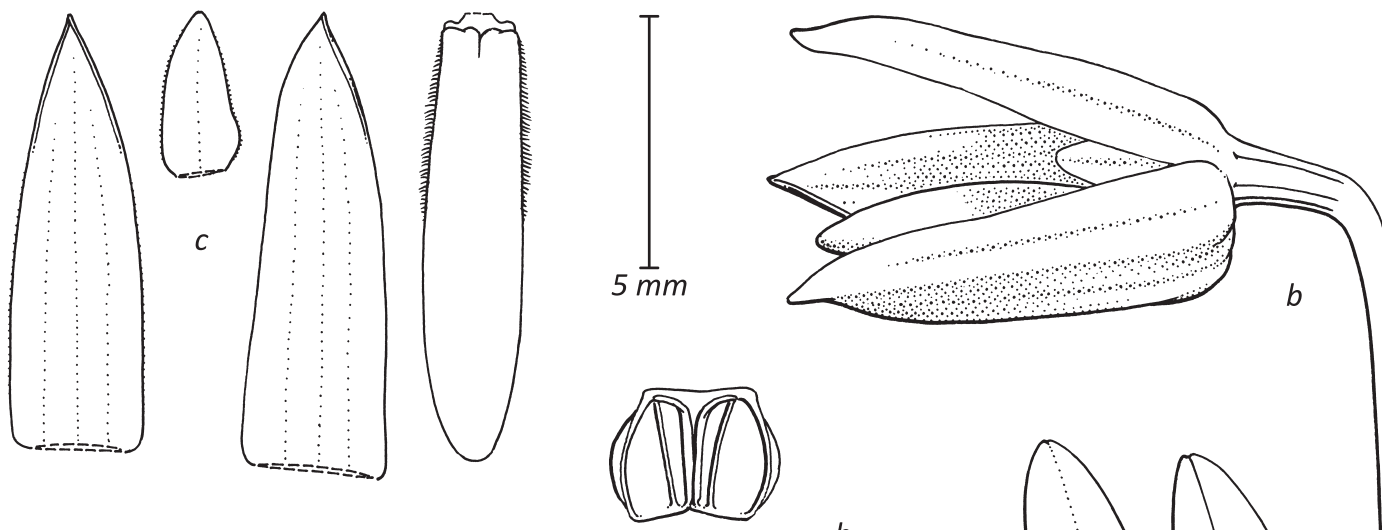

$h$

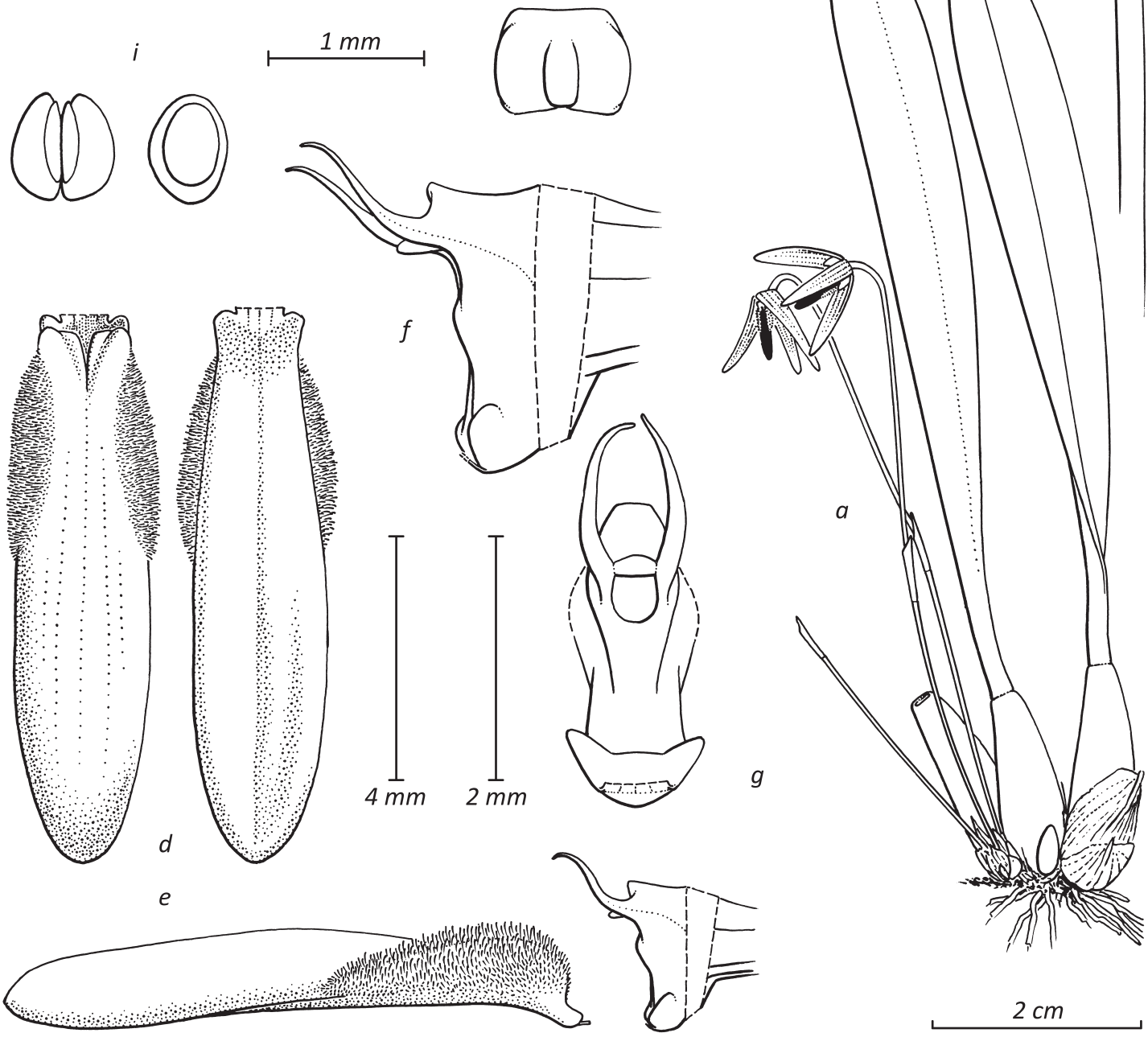

FiguRE 7. Bulbophyllum schistopogon J.J.Verm., Schuit. \& de Vogel. a. Habit. b. Flower. c. Flower analysis, from left to right: median sepal, petal, lateral sepal, lip. d. Lip, left: adaxial side, right: abaxial side. e. Column and lip, lateral view. f. Column, lateral view. g. Column, frontal view;. h. Anther, above: adaxial side, below: abaxial side. i. Pollinia, left: two pairs, right: one pair. Drawn from Reeve 1016 by $(\mathcal{C}$ J.J. Vermeulen, from herbarium material. 
between pseudobulbs $0.1-0.9 \mathrm{~cm}$ long, arising from the basal node of the pseudobulb; rhizome scales thin, somewhat persistent. Pseudobulbs distinct, ovoid(cylindrical), $1.1-2.1 \times 0.4-0.7 \mathrm{~cm}$, hardly angular. Leaf: petiole $0.5-1.3 \mathrm{~mm}$ long; blade obovate, $3.0-7.0 \times 0.5-0.9 \mathrm{~cm}$, ratio length/width 5.0-12.8; obtuse. Inflorescences single or several together, 5-8 cm long, 1-flowered. Peduncle $1.8-3.3 \mathrm{~cm}$ long, scales ca. 2, basal. Floral bracts $4.0-7.0 \mathrm{~mm}$ long. Flowers: pedicel plus ovary $21-36 \mathrm{~mm}$ long, basal node $2.6-4.0 \mathrm{~mm}$ above the floral bract attachment. Median sepal free, recurved, ovate(-triangular), $9.0-11.0 \times 2.5-3.0 \mathrm{~mm}$, ratio length/width 3.2-3.7; acute, margins entire, glabrous to minutely papillose, surface glabrous; 3-veined. Lateral sepals as the median but (ovate-)triangular, $8.0-12.0 \times 2.2-3.5$ $\mathrm{mm}$, ratio length/width 3.0-4.6, margins glabrous. Petals porrect, ovate-triangular, 2.6-3.2 × 1.0-1.9 $\mathrm{mm}$, ratio length/width 1.6-3.0; obtuse, margins entire, minutely papillose, surface glabrous; 1-veined. Lip slightly recurved near base, elliptic, 7.5-9.0 $\times$ 1.8-2.2 mm, ratio length/width 3.7-4.5 (without spreading); rounded to obtuse, margins entire, densely hirsute proximally, glabrous distally; thick; adaxially concave close to the base, this cavity bordered by two short, converging ridges with a glabrous crest, adaxial surface otherwise approx. flat and with two densely hirsute patches towards the margins in the proximal $2 / 5-1 / 2$ of its length, slightly convex and glabrous elsewhere; abaxially slightly convex near the base, slightly concave elsewhere, surface glabrous. Column including stelidia 1.6-2.3 mm long, stigma approx. circular, proximally distinctly protruding from the column face, foot distally widened, with spreading, obtuse lateral teeth. Stelidia sigmoid, narrowly triangular, distally subulate, $0.8-1.3 \mathrm{~mm}$ long, acute. Pollinia 4, the inner more than half as long as the outer.

CoLours: sepals purple with darker veins. Petals and lip dark purple, hairy patches white.

Eтүмодоgy: schistos $($ Greek) = split, pogon $($ Greek $)=$ beard, referring to the 'sideburns' along the proximal part of the lip.

Habitat AND ECOLOGY: epiphyte, no further details. Elevation $2400 \mathrm{~m}$.
Bulbophyllum stagmatoglossum J.J.Verm., Schuit. \& de Vogel, sp. nov. (Fig. 8)

TYPE: Indonesia, Papua Province, $9 \mathrm{~km}$ Northeast of Lake Habbema, 2800 m alt., October 1938, Brass 10538 (holotype AMES!).

Diagnosis. Most similar to Bulbophyllum exilipes Schltr., differs by the ovate petals (versus broadly ovate and distinctly attenuated half-way their length), the upwards falcate (versus downwards falcate) stelidia, and the papillose (versus glabrous) ridges on the adaxial side of the lip.

Rather small epiphyte with creeping rhizomes and spreading roots. Rhizome $2.0-3.0 \mathrm{~mm}$ diam., sections between pseudobulbs $0.2-0.9 \mathrm{~cm}$ long, arising from the basal node of the pseudobulb; rhizome scales thin, little persistent. Pseudobulbs distinct, ovoid, 0.6-2.0 $\times 0.3-0.6 \mathrm{~cm}$, (?)angular. Leaf: petiole 5-9 mm long; blade elliptic(-oblong) to obovate(-oblong), 2.9-8.0 $\times 0.4-1.0 \mathrm{~cm}$, ratio length/width 6.4-13.7; obtuse. Inflorescences single or few together, $10-11 \mathrm{~cm}$ long, 1-flowered. Peduncle 5.5-6.0 cm long, scales ca. 3. Floral bracts ca. $5 \mathrm{~mm}$ long. Flowers: pedicel plus ovary ca. $3.8 \mathrm{~cm}$ long, basal node ca. $3 \mathrm{~mm}$ above the floral bract attachment. Median sepal free, recurved, ovate, $5.8-9.5 \times 2.3-3.2 \mathrm{~mm}$, ratio length/width 2.5-3.0; acute, margins entire, minutely papillose; glabrous, 3-veined. Lateral sepals as the median, but triangular, 5.9-12.5 × 2.4-3.5 mm, ratio length/width 2.4-3.6, margins glabrous. Petals porrect, ovate, 3.0$4.0 \times 1.5-1.8 \mathrm{~mm}$, ratio length/width 2.0-2.3; rounded, margins minutely erose, papillose to ciliolate, surface glabrous; 1-veined. Lip approx. straight, proximally ovate, tapering into a narrow, oblong apical part with a slightly thickened apex, 5.0-6.5 × 1.6-1.7 mm, ratio length/width 3.1-3.9 (without spreading); rounded, margins entire, hirsute proximally, glabrous distally; thick; adaxially concave proximally and with two converging, distinct, rounded, distinctly papillose ridges which grade into the convex distal part at about $2 / 5-1 / 2$ of the length of the lip, also with two much shorter, converging ridges close to the base, adaxial surface otherwise glabrous; abaxially with a deep median furrow from base to apex, otherwise convex and densely hirsute proximally, slightly concave and glabrous elsewhere. Column including stelidia 1.9-2.0 


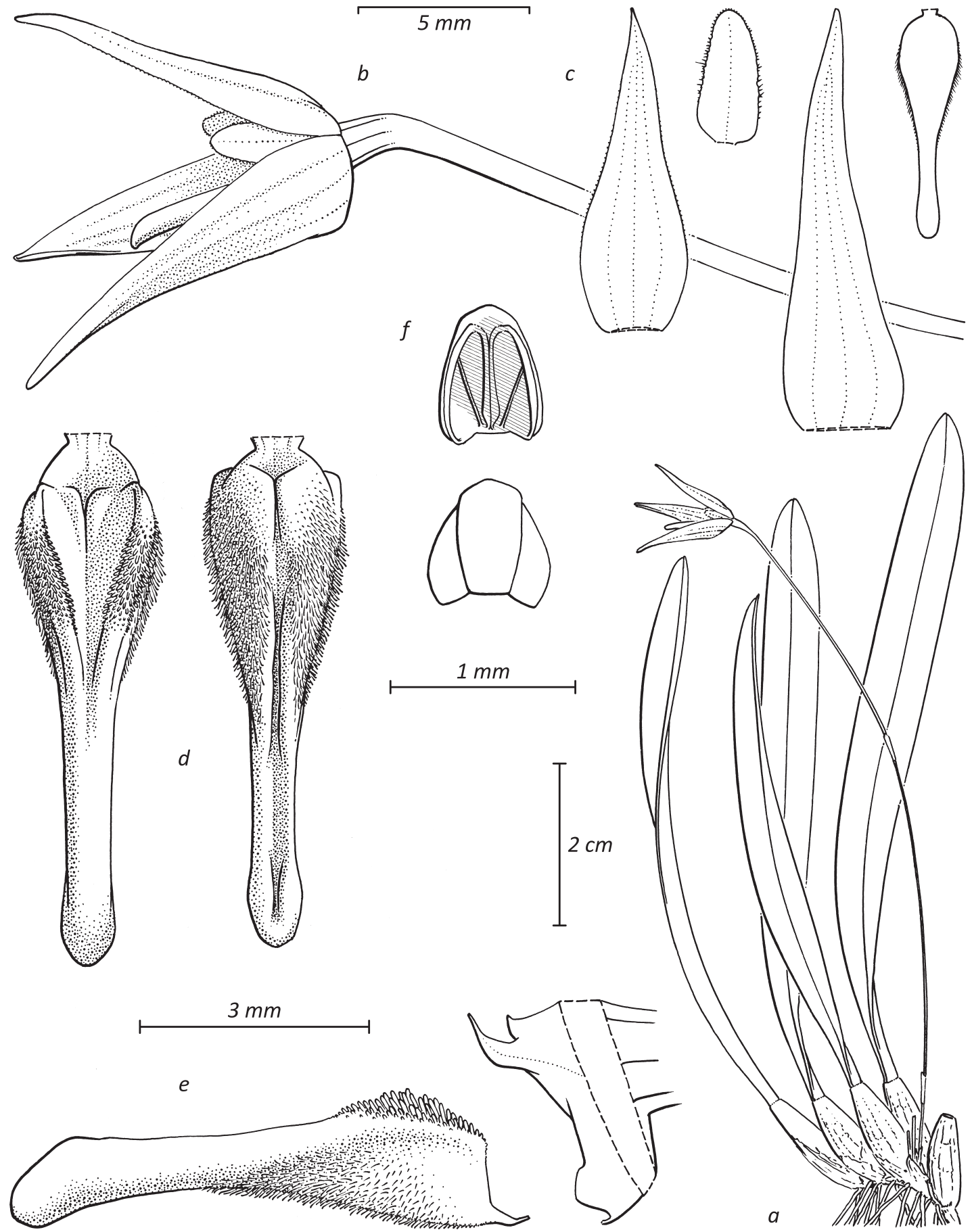

Figure 8. Bulbophyllum stagmatoglossum J.J.Verm., Schuit. \& de Vogel. a. Habit. b. Flower. c. Flower analysis, from left to right: median sepal, petal, lateral sepal, lip. d. Lip, left: adaxial side, right: abaxial side. e. Column and lip, lateral view. f. Anther, above: adaxial side, below: abaxial side. Drawn from Brass 10538 by C J.J. Vermeulen, from herbarium material. 


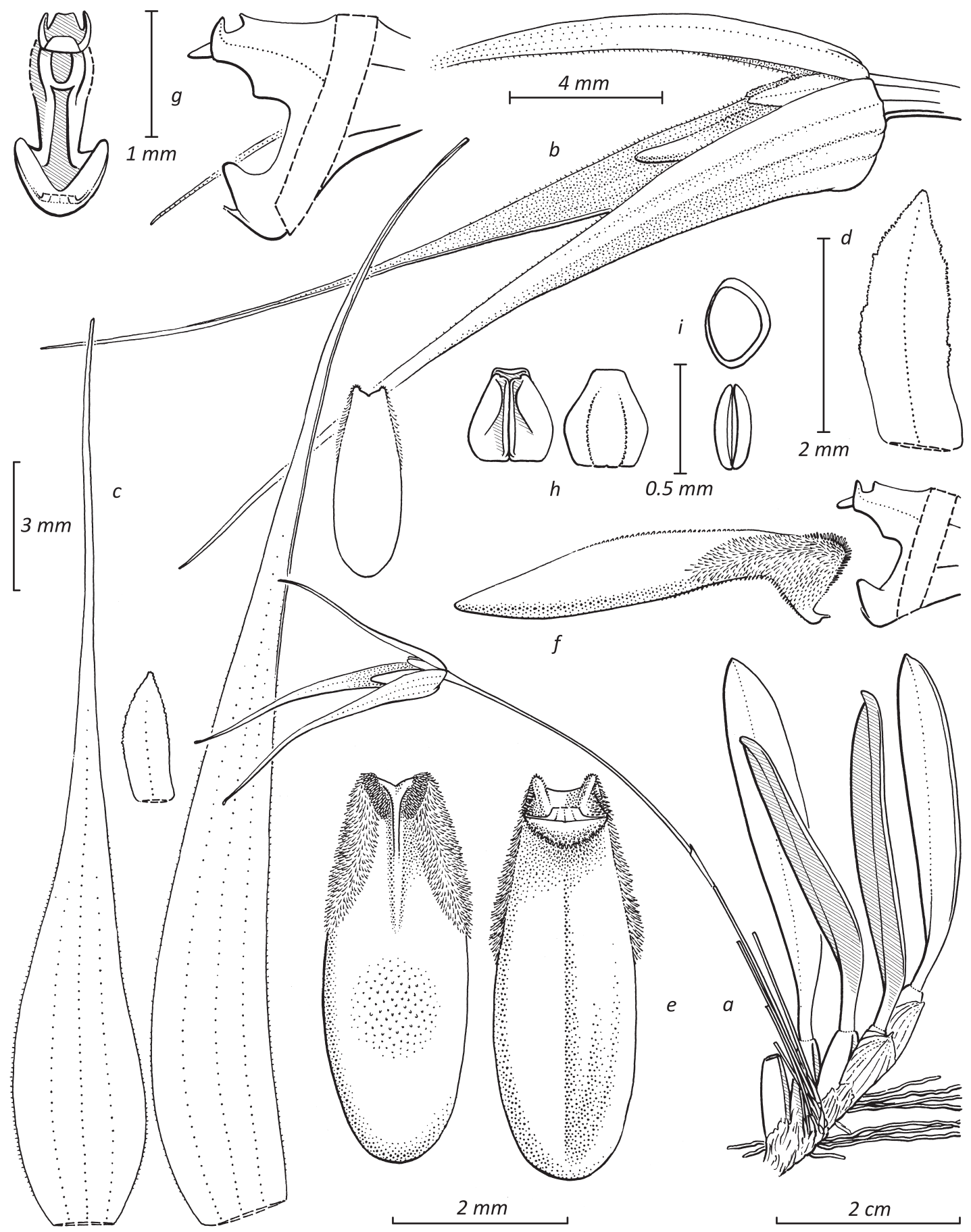

Figure 9. Bulbophyllum subium J.J.Verm., Schuit. \& de Vogel. a. Habit. b. Flower. c. Flower analysis, from left to right: median sepal, petal, lateral sepal, lip. d. Petal. e. Lip, left: adaxial side, right: abaxial side. f. Column and lip, lateral view. g. Column, left: frontal view; right: lateral view. h. Anther, left: adaxial side, right: abaxial side. i. Pollinia, above: one pair, below: two pairs. Drawn from Johns 9057 by (C) J.J. Vermeulen, from herbarium material. 
$\mathrm{mm}$ long, stigma narrowly obovate, foot distinctly widened, with patent, obtuse lateral teeth. Stelidia upwards falcate, narrowly triangular, subulate distally, 0.8-0.9 mm long, acute. Pollinia 4.

CoLours: sepals and petals pale purple with darker specklings. Lip yellow, apex purple.

Etymology: stagma (Greek) = drop, glossa (Greek) tongue, referring to the outline of the lip.

HaBITAT AND ECOLOGY: tufted on mossy trees. Elevation $2800-2900 \mathrm{~m}$.

Bulbophyllum subium J.J.Verm., Schuit. \& de Vogel, sp. nov. (Fig. 9)

TYPE: Indonesia, Papua Province, Mimika Regency, PT-Freeport Indonesia Concession Area, below Hanekam Tunnel, $2500 \mathrm{~m}$ alt., 15 Oct. 1998, Johns 9057 (holotype K!, isotypes BO, L!, MAN, FREE).

DiAGNOSIS. Shares the clustered growth, combined with narrow sepals and short, upwards falcate stelidia with Bulbophyllum galliaheneum Van Royen, from which it differs by the elliptic to ovate, acute (versus obovateoblong, subtruncate to rounded) petals, by the much denser and larger hirsute patches proximally on the adaxial side of the lip, and by the triangular (versus narrowly triangular and distally subulate) stelidia; and with $B$. odontopetalum Schltr., from which it differs by the elliptic to ovate, minutely erose and/or ciliolate (versus obovate-spathulate, coarsely fimbriate) petals, and by the hirsute (versus glandular-papillose) lip margins.

Small epiphyte with creeping rhizomes and spreading roots. Rhizome ca. $2.5 \mathrm{~mm}$ diam., sections between pseudobulbs $0.3-0.5 \mathrm{~cm}$ long, arising from the basal node of the pseudobulb; rhizome scales thin, little persistent. Pseudobulbs distinct, ellipsoid, 1.0$1.2 \times 0.3-0.4 \mathrm{~cm}$, hardly angular but concave on the side where the new shoot arises. Leaf: petiole $0.5-1.5$ $\mathrm{mm}$ long; blade elliptic to obovate, $2.9-6.0 \times 0.5-0.7$ $\mathrm{cm}$, ratio length/width 4.1-12; subacute. Inflorescences single or several together, ca. $8 \mathrm{~cm}$ long, 1-flowered. Peduncle ca. $4.5 \mathrm{~cm}$ long, scales ca. 4 . Floral bracts ca. $4.0 \mathrm{~mm}$ long. Flowers: pedicel plus ovary ca. 9 $\mathrm{mm}$ long, basal node ca. $2 \mathrm{~mm}$ above the floral bract attachment. Median sepal free, recurved, ovate, ca. 22 $\times 3.2 \mathrm{~mm}$, ratio length/width 6.8-6.9; long-acuminate, margins entire, ciliolate, surface glabrous; 3 -veined. Lateral sepals as the median but ovate-triangular, ca. $28.5 \times 3.0 \mathrm{~mm}$, ratio length/width ca. 9.5. Petals porrect, elliptic to ovate, $3.1-4.5 \times 1.0-1.1 \mathrm{~mm}$, ratio length/width 2.8-4.5; acute, margins minutely erose and/or ciliolate, surface glabrous; 1-veined. Lip slightly recurved near base, elliptic to oblong, 4.6-5.0 $\times 1.3-1.8 \mathrm{~mm}$, ratio length/width 2.5-3.9 (without spreading); rounded, margins entire, approx. densely hirsute proximally, glabrous distally; thick; adaxially concave close to the base, this cavity with a proximally widening, glabrous median crest which continues up to $1 / 3-2 / 5$ of the length of the lip, the cavity bordered by two short, converging ridges with a densely papillose crest, adaxial surface otherwise slightly concave and with two densely hirsute patches towards the margins in the proximal $1 / 3-2 / 5$ of its length, slightly convex and slightly papillose elsewhere; abaxially convex and shortly hirsute with scattered glandular papillae near the base, slightly concave and glabrous elsewhere. Column including stelidia $0.9-1.2 \mathrm{~mm}$ long, stigma elliptic, proximally distinctly protruding from the column face, foot deeply furrowed, distally distinctly widened, with spreading, obtuse lateral teeth. Stelidia upwards falcate, triangular, $0.3-0.4 \mathrm{~mm}$ long, acute. Pollinia 4.

Colours: flowers dark red-purple.

ETymology: subium (Latin) = moustache, referring to shape of the hairy patches on the lip (the word is used as a noun in apposition.

Habitat And eCology: epiphyte in Casuarina forest. Elevation $2500 \mathrm{~m}$.

Bulbophyllum teinodragma J.J.Verm., Schuit. \& de Vogel, sp. nov. (Fig. 10)

TYPE: Papua New Guinea, Normanby Island, Mt Pabinama, 700 m, 8 May 1956, Brass 25777 (holotype L!; isotype AMES!).

Diagnosis. Identified within section Polymeres by the distinctly elongated fertile sympodia from which inflorescences develop. In addition, it differs from Bulbophyllum melinanthum Schltr, which is the most similar species, by its obovate (versus ovate), sparsely ciliolate (versus entire to minutely papillose) petals. 

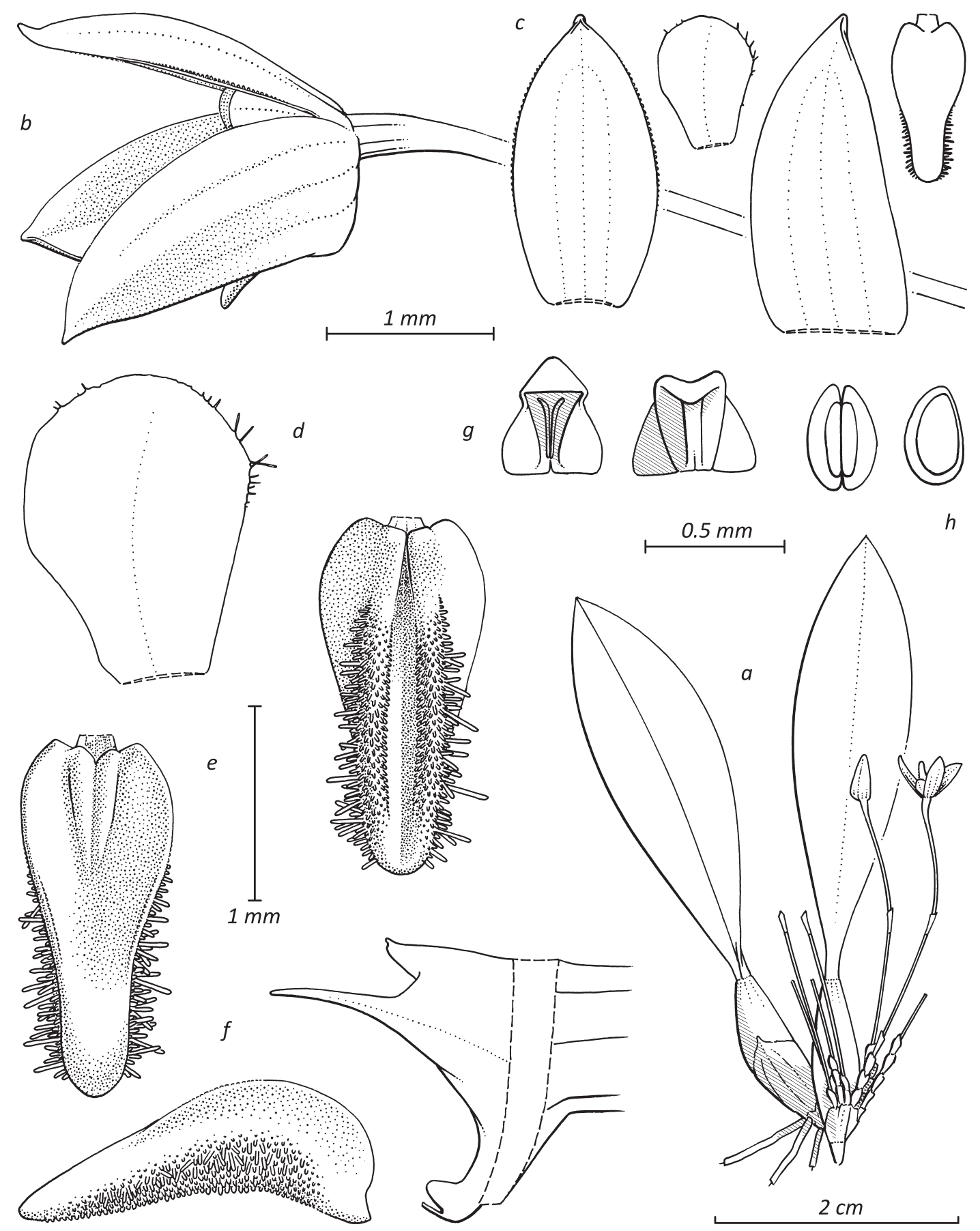

FIgURE 10. Bulbophyllum teinodragma J.J.Verm., Schuit. \& de Vogel. a. Habit. b. Flower. c. Flower analysis, from left to right: median sepal, petal, lateral sepal, lip. d. Petal. e. Lip, left: adaxial side, right: abaxial side. f. Column and lip, lateral view. g. Anther, left: adaxial side, right: abaxial side. h. Pollinia, left: two pairs, right: one pair. Drawn from Brass 25777 by (C) J.J. Vermeulen, from herbarium material. 
Small epiphyte with creeping rhizomes and spreading roots. Rhizome ca. $1.2 \mathrm{~mm}$ diam., sections between pseudobulbs $0.2-0.3 \mathrm{~cm}$ long, arising from the basal node of the pseudobulb; rhizome scales thin, little persistent. Pseudobulbs distinct, ovoid, $1.2-1.4 \times 0.3-0.4 \mathrm{~cm},($ ?)angular. Leaf: petiole $3-4$ $\mathrm{mm}$ long; blade elliptic to obovate, $3.0-4.2 \times 0.7-0.8$ $\mathrm{cm}$, ratio length/width 4.1-5.8; acute. Inflorescences many together on a distinctly elongated, sparsely branched sympodium, 2.3-3.0 cm long, 1-flowered. Peduncle $1.0-1.5 \mathrm{~cm}$ long, scales 1. Floral bracts 1.8-2.3 mm long. Flowers: pedicel plus ovary $10-12 \mathrm{~mm}$ long, basal node $0.8-2.0 \mathrm{~mm}$ above the floral bract attachment. Median sepal free, recurved, elliptic, $3.4-3.7 \times 1.7-1.8 \mathrm{~mm}$, ratio length/width 1.8-2.1; apiculate, margins entire, minutely papillose; glabrous, 3-veined. Lateral sepals as the median, but ovate-triangular, $3.4-4.5 \times 1.5-2.0 \mathrm{~mm}$, ratio length/ width 2.0-2.3, acute to apiculate, margins glabrous. Petals porrect, obovate, $1.6-2.0 \times 1.0-1.2 \mathrm{~mm}$, ratio length/width 1.4-1.7; rounded, margins slightly erose, sparsely ciliolate, surface glabrous; 1-veined. Lip slightly curved, ovate, slightly attenuated in the distal half, tapering into a short, oblong apical part, 1.7-2.0 $\times 0.8-1.1 \mathrm{~mm}$, ratio length/width 1.8-2.3 (without spreading); rounded, margins entire, approx. glabrous; thick; adaxially concave proximally and with two parallel, short, distally somewhat tapering ridges close together near the base, distally slightly convex, adaxial surface glabrous; abaxially with a deep median furrow from base to apex bordered by two distinct, rounded, papillose ridges. Column including stelidia ca. $1.4 \mathrm{~mm}$ long, stigma narrowly obovate, foot widened, with patent, obtuse lateral teeth. Stelidia straight, narrowly triangular, subulate distally, ca. $0.7 \mathrm{~mm}$ long, acute. Pollinia 4, the inner more than half as long as the outer.

Colours: unknown.

ETYMology: teinos $($ Greek $)=$ stretched, $\operatorname{dragma}($ Greek $)$ sheaf, referring to the elongated fertile sympodia.

Habitat AND ECOLOGY: low epiphyte in rainforest. Elevation $700 \mathrm{~m}$.

Bulbophyllum trivenosum J.J.Verm., Schuit. \& de Vogel, sp. nov. (Fig. 11)

TYPE: Papua New Guinea, East Sepik Province,
Hunstein Range, 1500 m alt., 5 Oct. 1989, LAE (Katik \& Kairo) 64395 (holotype L!; isotypes LAE, NSW).

Diagnosis. Most similar to Bulbophyllum ischnopus Schltr. and B. melinanthum Schltr., differs from both by its 3-veined petals; in addition, it differs from the first by the shorter and thicker papillae on the abaxial surface of its lip, from the second by its oblong (versus ovate) petals.

Small epiphyte with creeping rhizomes and spreading roots. Rhizome $0.8-1.0 \mathrm{~mm}$ diam., sections between pseudobulbs $1.0-4.0 \mathrm{~cm}$ long, arising from the basal node of the pseudobulb; rhizome scales thin, little persistent. Pseudobulbs distinct, ovoid, 9.5-11 $\times$ 1.5-2.0 mm, (?)angular. Leaf: petiole $1.3-2.0 \mathrm{~mm}$ long; blade elliptic-oblong, $1.0-1.7 \times 0.2-0.4 \mathrm{~cm}$, ratio length/width 3.8-8.5; obtuse. Inflorescences single or a few together, ca. $3.5 \mathrm{~cm}$ long, 1-flowered. Peduncle ca. $1.9 \mathrm{~cm}$ long, scales ca. 2. Floral bracts ca. $2 \mathrm{~mm}$ long. Flowers: pedicel plus ovary ca. $9.5 \mathrm{~mm}$ long, basal node ca. $1.2 \mathrm{~mm}$ above the floral bract attachment. Median sepal free, recurved, elliptic, ca. $4.5 \times 1.8 \mathrm{~mm}$, ratio length/width ca. 2.5; acute-acuminate, margins entire, minutely papillose; glabrous, 3-veined. Lateral sepals as the median, but triangular, ca. $4.4 \times 2.0 \mathrm{~mm}$, ratio length/width 2.1, acute, margins glabrous. Petals porrect, oblong, ca. $2.1 \times 1.0 \mathrm{~mm}$, ratio length/width ca. 2.1; rounded, margins entire, minutely papillose, surface glabrous; 3-veined. Lip slightly curved, ovateoblong, slightly attenuated at ca. 1/3 of its length, ca. $2.8 \times 0.8 \mathrm{~mm}$, ratio length/width ca. 3.5 (without spreading); obtuse, margins entire, papillose at ca. $1 / 3$ of its length, otherwise glabrous; thick; adaxially concave proximally, slightly concave distally, surface glabrous; abaxially with hardly a median furrow, convex, papillose but glabrous near base and apex. Column including stelidia ca. $1.7 \mathrm{~mm}$ long, stigma narrowly elliptic with the proximal edge slightly protruding, foot widened, with slight, patent, obtuse lateral teeth. Stelidia slightly downwards falcate, narrowly triangular, subulate distally, ca. $1.0 \mathrm{~mm}$ long, acute. Pollinia not seen..

CoLours: flowers yellow and purple (?, label unclear).

ETYMology: tres $($ Latin) $=$ three, venosus $($ Latin) veined.

HABITAT AND ECOLOGY: epiphyte in rainforest ca. $2 \mathrm{~m}$ above the ground. Elevation $1500 \mathrm{~m}$. 


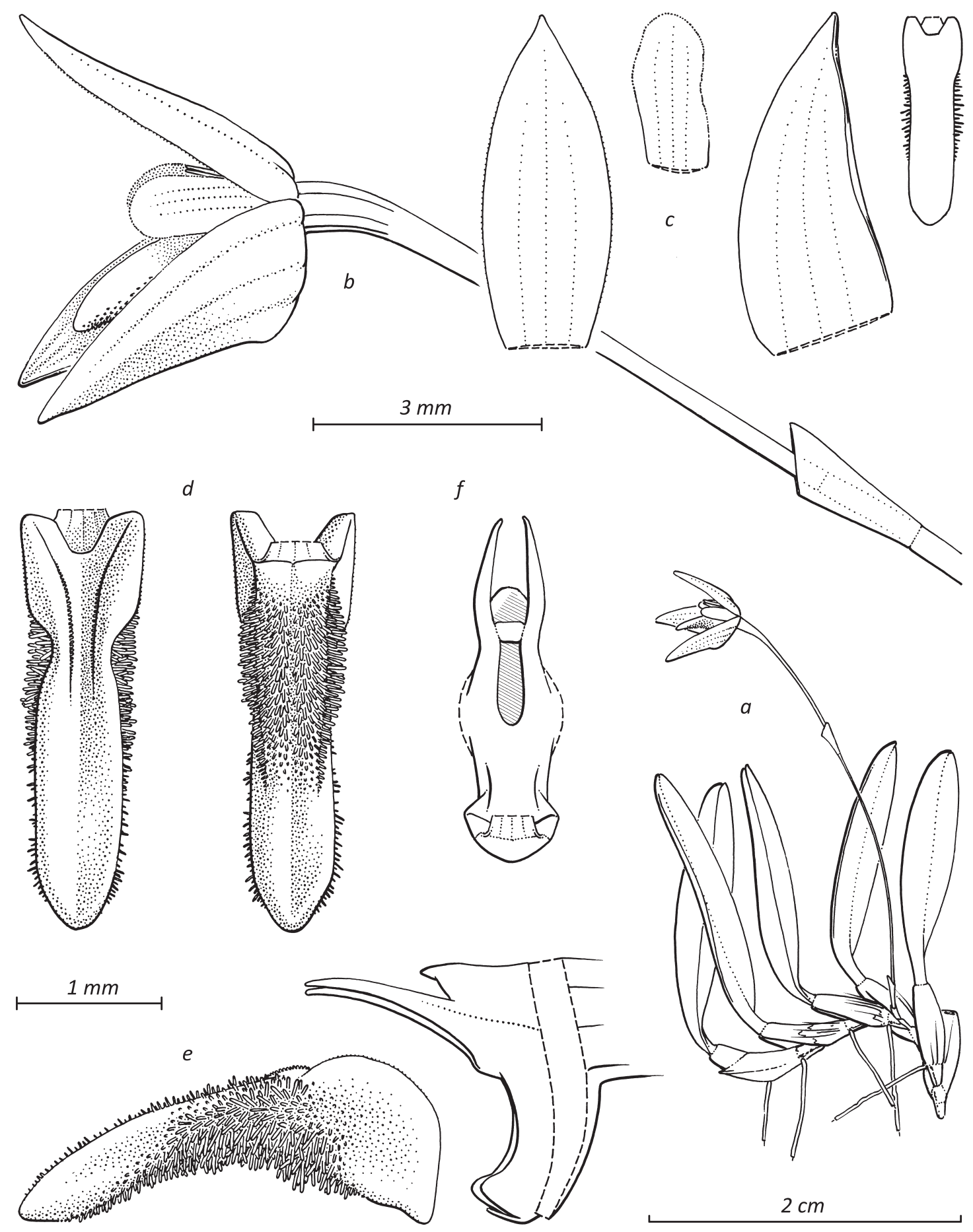

Figure 11. Bulbophyllum trivenosum J.J.Verm., Schuit. \& de Vogel. a. Habit. b. Flower. c. Flower analysis, from left to right: median sepal, petal, lateral sepal, lip. d. Lip, left: adaxial side, right: abaxial side. e. Column and lip, lateral view. f. Column, frontal view. Drawn from LAE (Katik \& Kairo) 64395 by C) J.J. Vermeulen, from herbarium material. 
Bulbophyllum section Polymeres (Bl.) J.J.Verm. \& O'Byrne - SERIES C.

Bulbophyllum farciminiferum J.J.Verm., Schuit. \& de Vogel, sp. nov. (Fig. 12, 18A)

TYPE: Papua New Guinea, no further data available, Jongejan cult. 1700 (holotype L!).

Diagnosis. Within series $\mathrm{C}$, the species is uniquely characterized by its terete leaves. It differs from Bulbophyllum radula, which has succulent, approx. semi-terete leaves, by its obovate, acuminate (versus ovate-oblong and rounded) petals and its narrower lip (ratio length/width ca. 3.2, versus 1.5-1.8).

Rather small epiphyte with patent, sparsely branched rhizomes to $15 \mathrm{~cm}$ long, over which the roots grow towards its base. Rhizome $1.1-1.5 \mathrm{~mm}$ diam., sections between pseudobulbs to $0.8 \mathrm{~cm}$ long, arising from the basal node of the pseudobulb; rhizome scales thin, little persistent. Pseudobulbs distinct, ellipsoid to obovoid, $0.6-0.9 \times 0.2-0.3 \mathrm{~cm}$, hardly angular but deeply concave on the side where the new shoot arises. Leaf: petiole $1.3-2.2 \mathrm{~mm}$ long; blade succulent, terete with a shallowly concave furrow on the adaxial side, ellipsoid to cylindrical, $12-27 \times 2.7-3.2 \mathrm{~mm}$, ratio length/width 4.4-8.4; obtuse to acute. Inflorescences densely clustered from the first node below the pseudobulbs, ca. $1 \mathrm{~cm}$ long, 1-flowered. Peduncle ca. $1 \mathrm{~mm}$ long, scales 1 . Floral bracts ca. $3.3 \mathrm{~mm}$ long. Flowers: pedicel plus ovary ca. $2.4 \mathrm{~mm}$ long, basal node ca. $1.8 \mathrm{~mm}$ above the floral bract attachment. Median sepal free, recurved, ovate, ca. $5.2 \times 1.6 \mathrm{~mm}$, ratio length/width 3.2-3.3; acuminate, margins entire, ciliolate, surface glabrous; 3-veined. Lateral sepals as the median but ca. $5.3 \times 1.9 \mathrm{~mm}$, ratio length/width 2.7-2.8. Petals porrect, obovate, ca. $1.5 \times 0.6 \mathrm{~mm}$, ratio length/width ca. 2.5 ; acuminate, margins entire, papillose-ciliate, surface finely papillose distally; 1-veined. Lip straight, oblong, ca. $3.2 \times 1.0 \mathrm{~mm}$, ratio length/width ca. 3.2 (without spreading); obtuse, margins entire, vesiculate with elongated vesicles proximally, glabrous distally; thick; adaxially concave close to the base, this cavity distally bordered by two short, converging ridges in front of which the adaxial surface is slightly concave, slightly convex in the distal half of the lip, adaxial surface papillose towards the edges in the proximal half, with larger vesicles close to the edge; abaxially slightly convex and papillose in the proximal half, slightly concave and glabrous elsewhere. Column including stelidia ca. $1.3 \mathrm{~mm}$ long, stigma elliptic, foot distally with spreading, rounded lateral teeth. Stelidia somewhat upwards falcate, narrowly triangular, ca. $0.6 \mathrm{~mm}$ long, acute. Pollinia 4 , the inner more than half as long as the outer.

CoLours: sepals pale purple, white towards the edges. Petals white. Lip purple, apex green, papillae pale purple, the larger white. Column white.

Eтүмоlogy: farcimen (Latin) = sausage, alluding to the leaf shape.

HABITAT AND ECOLOGY: not known.

Bulbophyllum gymnothema J.J.Verm., Schuit. \& de Vogel, sp. nov. (Fig. 13)

TYPE: Papua New Guinea, Chimbu Province, Mount Wilhelm, between Kombugomambuno moraine and Keglsugl, $2900 \mathrm{~m}$ alt., 9 July 1980, Goetghebeur \& Coppejans 3782 (holotype L! 0738050; isotypes L! (spirit material), GENT (herbarium and spirit material)).

Diagnosis. Within series C, it shares the partly bare rhizome (not entirely covered by scales) with Bulbophyllum nudicaule and B. tricaudatum J.J. Verm. It differs from the first by the narrower sepals (median sepal ratio length/width 3.7-3.8, versus $1.5-2.1$ ) as well as by the almost glabrous lip with only slightly and minutely papillose margins towards its base (versus coarsely papillose except near apex). It differs from the second by the ovate-oblong lip (versus lip divided into an obovate-oblong, wide basal part and a linear, narrow apical part).

Medium-sized epiphyte with patent, branched rhizomes. Rhizome ca. $3.0 \mathrm{~mm}$ diam., sections between pseudobulbs ca. $2.5 \mathrm{~cm}$ long, arising from the basal node of the pseudobulb; rhizome scales thin, leaving parts of the rhizome bare, rather persistent. Pseudobulbs distinct, cylindrical, 2.4-3.0 × 0.3-0.4 $\mathrm{cm}$. Leaf: petiole $2.0-5.0 \mathrm{~mm}$ long; blade elliptic to ovate, $4.4-5.2 \times 0.6-1.0 \mathrm{~mm}$, ratio length/width 4.9-7.4; acute. Inflorescences single or few together from nodes along the rhizome, $2.9-3.3 \mathrm{~cm}$ long, 

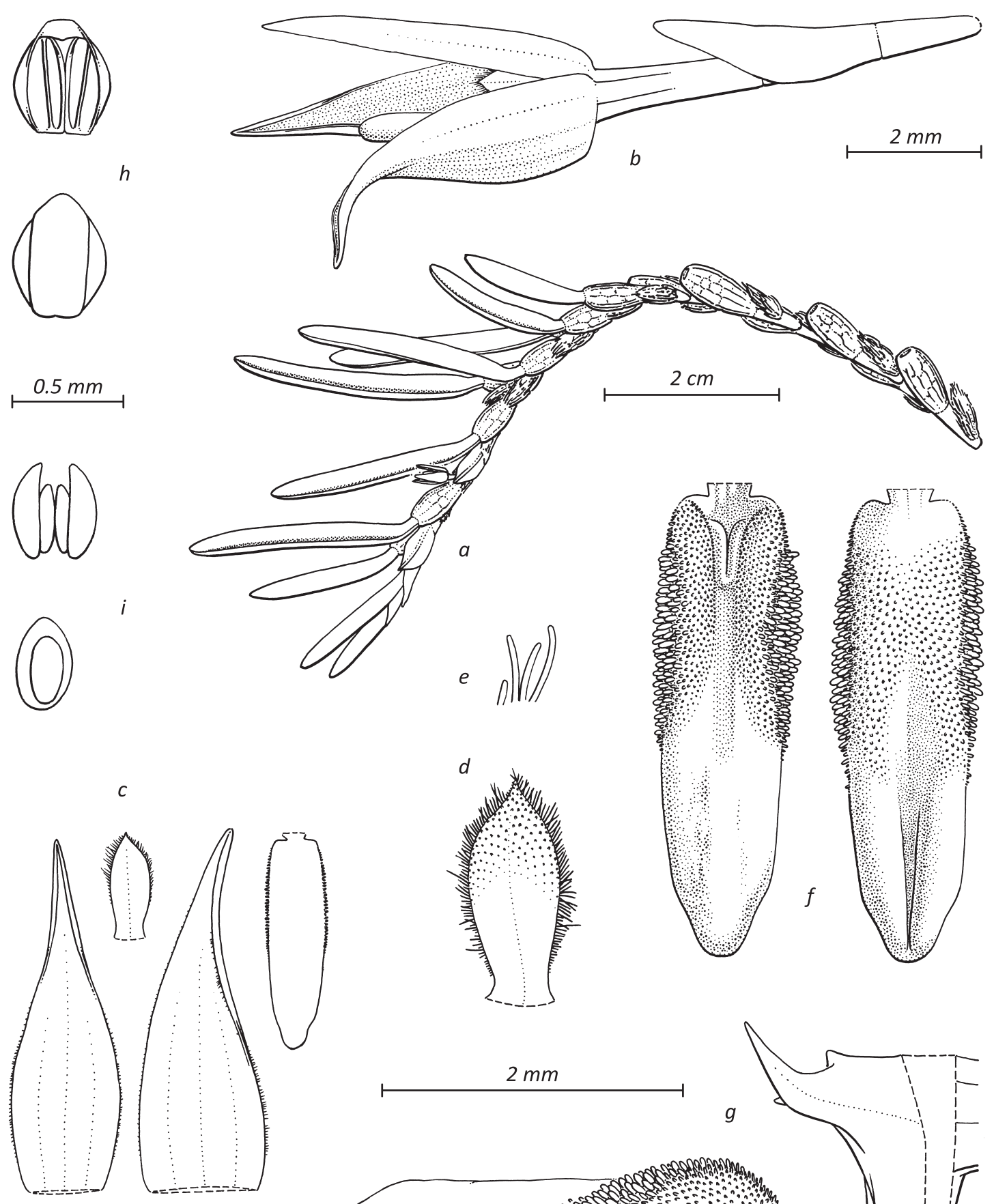

$2 \mathrm{~mm}$

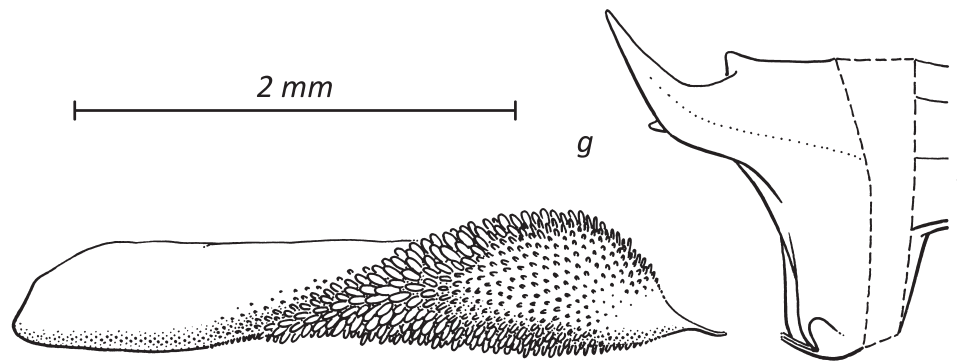

FiguRE 12. Bulbophyllum farciminiferum J.J.Verm., Schuit. \& de Vogel. a. Habit. b. inflorescence. c. Flower analysis, from left to right: median sepal, petal, lateral sepal, lip. d. Petal. e. Petal, detail of margin. f. Lip, left: adaxial side, right: abaxial side. g. Column and lip, lateral view. h. Anther, above: adaxial side, below: abaxial side. i. Pollinia, above: two pairs, below: one pair. Drawn from Jongejan cult. 1700 by $@$ J.J. Vermeulen, from spirit material. 


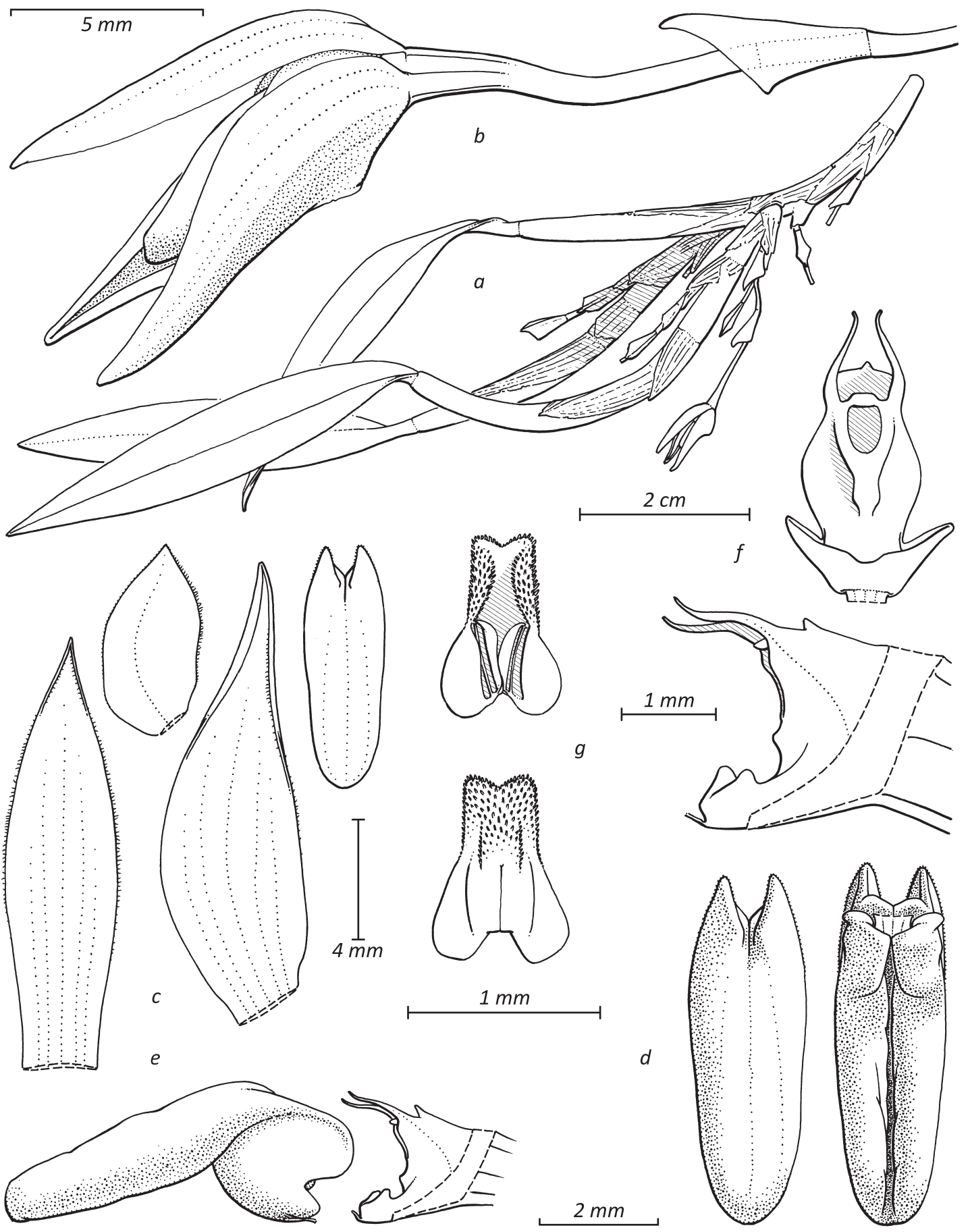

FIgURE 13. Bulbophyllum gymnothema J.J.Verm., Schuit. \& de Vogel. a. Habit. b. Flower. c. Flower analysis, from left to right: median sepal, petal, lateral sepal, lip. d. Lip, left: adaxial side, right: abaxial side. e. Column and lip, lateral view. f. Column, above: frontal view; below: lateral view. g. Anther, above: adaxial side, below: abaxial side. Drawn from Goetghebeur 3782 by (C) J.J. Vermeulen, from herbarium material. 
1-flowered. Peduncle 9-11 mm long, scales 3. Floral bracts $5.0-5.5 \mathrm{~mm}$ long. Flowers: pedicel plus ovary 9.0-10.0 mm long, basal node 3.0-3.5 $\mathrm{mm}$ above the floral bract attachment. Median sepal free, recurved, elliptic, ca. $11.2 \times 3 \mathrm{~mm}$, ratio length/width 3.7-3.8; acuminate, margins entire, distally ciliolate, surface glabrous; 5-veined. Lateral sepals as the median but ovate, ca. $11.5 \times 3.5 \mathrm{~mm}$, ratio length/width 3.2-3.3, upper margin glabrous. Petals porrect, elliptic-ovate, ca. $5.0 \times 2.5 \mathrm{~mm}$, ratio length/width ca. 2 ; acuteacuminate, margins entire, upper papillose, lower ciliolate, surface glabrous; 1-veined. Lip recurved in the basal half, ovate-oblong, ca. $6.2 \times 2.2 \mathrm{~mm}$, ratio length/width 2.8-2.9 (without spreading); rounded, margins entire, slightly and minutely papillose proximally, surface glabrous; very thick; adaxially concave close to the base and with two short, narrow ridges which start near the margins and then converge, leaving a wide gap in between, surface elsewhere convex, abaxially convex with a deep median furrow. Column including stelidia ca. $2.5 \mathrm{~mm}$ long, stigma elliptic, with a protruding callus just below it, foot distally widened, triangular, with small, patent, obtuse lateral lobes near the apex. Stelidia slightly sigmoid, triangular-subulate, ca. $1.7 \mathrm{~mm}$ long, acute.

Colours: unknown.

EтүмоLogy: gymnos $($ Greek) $=$ naked, thema $($ Greek $)$ $=$ stem, referring to the rhizome which is not entirely covered by bracts.

HABITAT AND ECOLOGY: not recorded. Elevation 2900 m.

Bulbophyllum lipochilum J.J.Verm., Schuit. \& de Vogel, sp. nov. (Fig. 14, 18C)

TYPE: Papua New Guinea, Central Province, Woitape, Mt. Alio South facing slope, at the North end of the valley, $2100 \mathrm{~m}$ alt., De Vogel \& Vogel (2002) s.n., L alca. 18379 (holotype L!, spirit material).

DiAgnosis. Most similar to Bulbophyllum chaunobulbon Schltr., with which it shares the scale-covered rhizome, the lax arrangement of the pseudobulbs and the glabrous lip. It differs by having wider petals (ratio length/width $1.4-1.5$, versus $1.7-3.0$ ), by the ovate lip with a drawn-out apex (versus oblong), and by the approx. porrect (versus sigmoid) stelidia.
Rather large epiphyte with pendulous, branched rhizomes to $50 \mathrm{~cm}$ long, some roots growing over the rhizome towards its base, others spreading. Rhizome 1.8-2.2 mm diam., sections between pseudobulbs 0.6-2.5 cm long, arising from the basal node of the pseudobulb; rhizome scales thin, little persistent. Pseudobulbs distinct, cylindrical-ovoid, 13-42 $\times$ 2.5-3.2 mm, hardly angular. Leaf: petiole $1.5-2.5 \mathrm{~mm}$ long; blade ovate, $32-72 \times 3.5-5.5 \mathrm{~mm}$, ratio length/ width 9.1-13.1; acute. Inflorescences single or a few together, ca. $3.5 \mathrm{~cm}$ long, 1-flowered. Peduncle 1.3$3.1 \mathrm{~cm}$ long, scales 3. Floral bracts $3.5-4.0 \mathrm{~mm}$ long. Flowers: pedicel plus ovary $8.0-10.0 \mathrm{~mm}$ long, basal node $1.5-3.0 \mathrm{~mm}$ above the floral bract attachment. Median sepal free, recurved, ovate-triangular, ca. $13.5 \times 2.4 \mathrm{~mm}$, ratio length/width 5.6-5.7; acuteacuminate, margins entire, minutely papillose, surface glabrous; 5-veined. Lateral sepals as the median but falcate, triangular, ca. $13.8 \times 4.0 \mathrm{~mm}$, ratio length/ width 3.4-3.5, margins glabrous. Petals porrect, ovate, ca. $5.2 \times 3.5 \mathrm{~mm}$, ratio length/width 1.4-1.5; acuminate, upper margin entire, glabrous, lower somewhat erose, densely papillose-ciliolate, surface glabrous; 1-veined. Lip recurved near the base, ovate with drawn-out apex, ca. $11.2 \times 1.8 \mathrm{~mm}$, ratio length/ width $6.2-6.3$ (without spreading); obtuse, margins entire, glabrous; very thick; adaxially concave close to the base and with two short, narrow ridges which start near the margins and then converge, leaving a wide gap in between, surface elsewhere convex, abaxially with a median furrow which is deep in the basal half, shallow elsewhere. Column including stelidia ca. $2.4 \mathrm{~mm}$ long, stigma narrowly obovate with slightly protruding base, foot distally widening. Stelidia approx. porrect, narrowly triangular, ca. 1.1 $\mathrm{mm}$ long, acute, upper and lower margin with a slight, deltoid, obtuse tooth. Pollinia 4, the inner more than half as long as the outer.

CoLours: tepals pale yellow-ochre, veins dull red, petals with a few blackish dots along the upper margin. Lip glossy, orange-yellow, proximally red, distally white.

Eтymology: lipos $($ Greek) = grease, cheilos $($ Greek) lip, referring to the shiny lip surface.

Habitat AND eCology: not recorded. Elevation $2200 \mathrm{~m}$. 


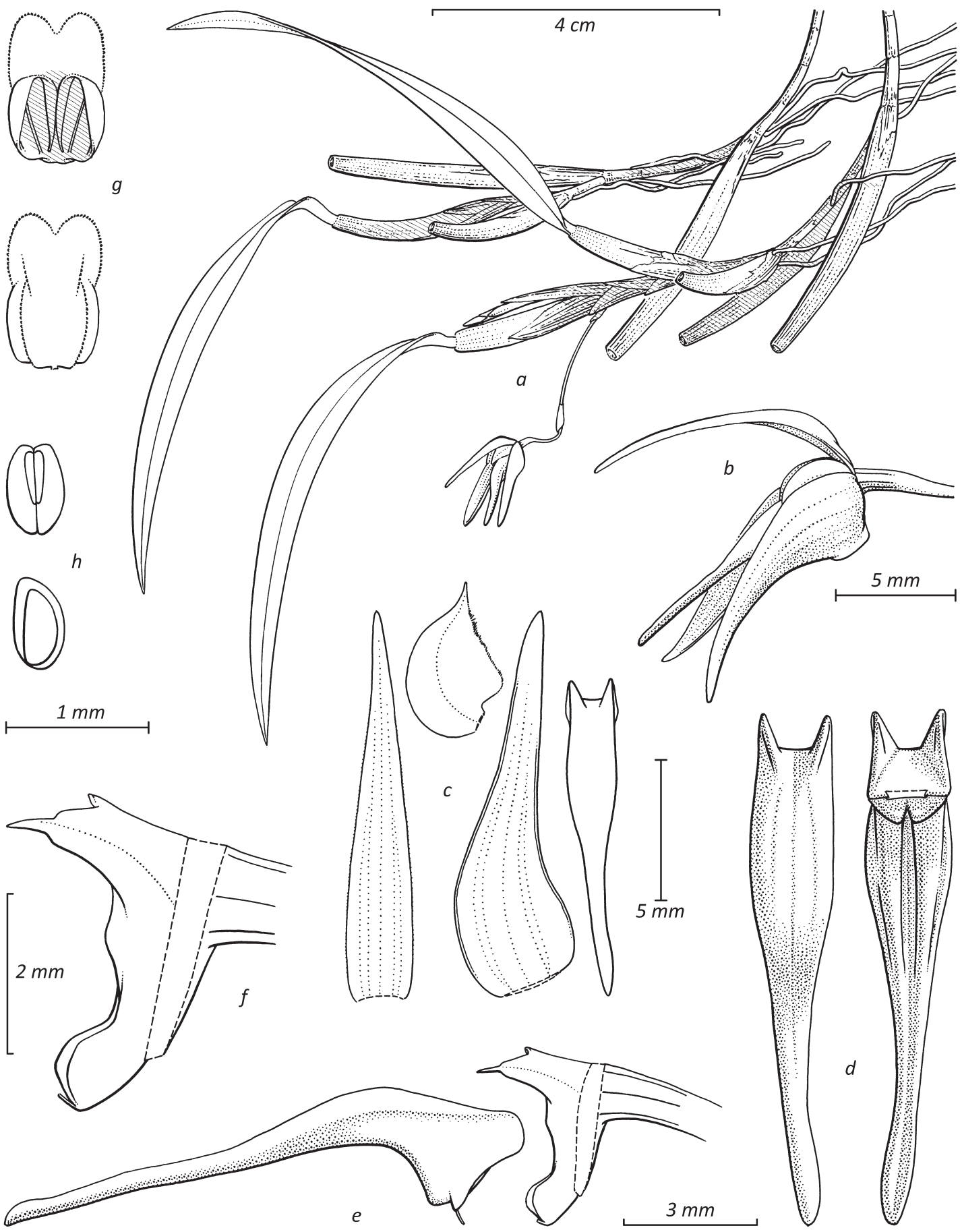

FIgURE 14. Bulbophyllum lipochilum J.J.Verm., Schuit. \& de Vogel. a. Habit. b. Flower. c. Flower analysis, from left to right: median sepal, petal, lateral sepal, lip. d. Lip, left: adaxial side, right: abaxial side. e. Column and lip, lateral view. f. Column, lateral view. g. Anther, above: adaxial side, below: abaxial side. h. Pollinia, above: two pairs, below: one pair. Drawn from de Vogel \& Vogel (2002) s.n., L alc. 18379 by (C J.J. Vermeulen, from spirit material. 
Bulbophyllum nudicaule J.J.Verm., Schuit. \& de Vogel, sp. nov. (Fig. 15)

TYPE: Papua New Guinea, Central Province, Owen Stanley Range, Boridi, 4700 ft, 8 Sep. 1935, Carr 10263 (holotype L! 1495892; isotypes AMES!, BM, K!, L! 1495893, L! 1495894, NY!, SING 0132016).

Diagnosis. Within series $\mathrm{C}$, it shares the partly bare rhizome (not entirely covered by scales) with Bulbophyllum gymnothema and B. tricaudatum J.J. Verm. It differs from both by the coarsely papillose lip margins.

Rather large epiphyte with patent to pendulous, sparsely branched rhizomes to $80 \mathrm{~cm}$ long, over which the roots grow towards its base. Rhizome $3.0-5.5 \mathrm{~mm}$ diam., sections between pseudobulbs $1.8-3.5 \mathrm{~cm}$ long, arising from the basal node of the pseudobulb; rhizome scales thin, leaving parts of the rhizome bare, little persistent. Pseudobulbs distinct, cylindrical, 2.8-5.3 $\times$ 0.5-0.6 cm. Leaf: petiole $2.5-7.0 \mathrm{~mm}$ long; blade ovate, $4.9-9.2 \times 0.8-1.4 \mathrm{~cm}$, ratio length/width 4.9-7.8; acute. Inflorescences solitary or few together, ca. $1.5 \mathrm{~cm}$ long, 1-flowered. Peduncle ca. $4.5 \mathrm{~mm}$ long, scales 1. Floral bracts ca. $4.6 \mathrm{~mm}$ long. Flowers: pedicel plus ovary ca. $4.6 \mathrm{~mm}$ long, basal node ca. $3.5 \mathrm{~mm}$ above the floral bract attachment. Median sepal free, recurved, elliptic to ovate, $6.0-7.2 \times 3.3-4.2 \mathrm{~mm}$, ratio length/width 1.5-2.1; acute, margins entire; glabrous; 3 -veined. Lateral sepals as the median but ovate, $7.0-8.8 \times 3.0-4.3 \mathrm{~mm}$, ratio length/width 1.8-3.0. Petals porrect, obovate-oblong, $3.0-3.8 \times 0.8-1.2 \mathrm{~mm}$, ratio length/width $3.0-3.8$; obtuse, margins entire; glabrous; 1-veined. Lip slightly recurved close to the base, elliptic, 4.5-5.2 × 2.2-2.4 $\mathrm{mm}$, ratio length/width 1.8-2.4 (without spreading); obtuse to acute, margins entire, coarsely papillose except near apex; rather thick; adaxially concave in the proximal $2 / 3$ because of slightly upturned, coarsely papillose edges, with a v-shaped furrow near the base bordered by two low, finely papillose ridges which distally meet and continue as a rounded, rather narrow, glabrous median ridge up to $2 / 3$ of the length of the lip, distal part of the lip slightly convex, adaxial surface otherwise glabrous; abaxially slightly convex, slightly furrowed distally, surface glabrous, papillose towards the edges. Column including stelidia 2.6-3.7 $\mathrm{mm}$ long, stigma obovate, foot distally widened and with spreading, rounded lateral teeth. Stelidia upwards falcate, narrowly triangular, $1.7-2.0 \mathrm{~mm}$ long, acute. Pollinia 4, the inner more than half as long as the outer.

Colours: sepals pale ochre, veins red-purple. Petals white, thickened part purple Lip purple, base and margins white, apex yellow.

ETYMology: nudus $($ Latin) $=$ naked, caulis $($ Latin $)=$ stem, referring to the rhizome which is not entirely covered by bracts.

Habitat And eCology: in forest on trees at $1425 \mathrm{~m}$.

Bulbophyllum radula J.J.Verm., Schuit. \& de Vogel, sp. nov. (Fig. 16)

Bulbophyllum "subcubium (?)", Dressler, The Orchids, P1. 13, fig. 73 (1981) [probably a spelling mistake for B. subcubicum J.J.Sm., an unrelated species].

TYPE: Papua New Guinea, Enga Province, Lagaip District, Yokotapus North of Laiagam station, 2400 m, March 1983, Reeve 762 (holotype L!; isotypes CANB, E!, K!, LAE, NSW).

Diagnosis. Within series $\mathrm{C}$, it shares a rhizome with rather densely set pseudobulbs combined with an abaxially hirsute lip with Bulbophyllum atroviride J.J. Verm. and B. planiplexum J.J. Verm. Bulbophyllum radula differs by the succulent, semi-terete leaves (thin and dorsoventrally flattened in the others), the (ovate-) oblong, rounded petals (ovate-triangular and acute in B. atroviride), and the wide lip (ratio length/width $1.5-1.8$, versus 5.5-5.8 in B. planiplexum).

Medium-sized epiphyte with patent to pendulous, sparsely branched rhizomes to $30 \mathrm{~cm}$ long, over which the roots grow towards its base. Rhizome 1.1-2.0 $\mathrm{mm}$ diam., sections between pseudobulbs $0.4-0.9 \mathrm{~cm}$ long, arising from the basal node of the pseudobulb; rhizome scales thin, rather persistent. Pseudobulbs distinct, ellipsoid to (ob-)ovoid, 0.6-1.1 × 0.3-0.4 cm, hardly angular but deeply concave on the side where the new shoot arises. Leaf: petiole 1.5-2.8 mm long; blade succulent, semi-terete with the adaxial side flattened, ovate in outline, $17-22 \times 3.5-7.0 \mathrm{~mm}$, ratio length/width 3.1-4.9; acute. Inflorescences clustered, ca. $1 \mathrm{~cm}$ long, 1-flowered. Peduncle ca. $1.4 \mathrm{~mm}$ long, scales 1. Floral bracts ca. $3.1 \mathrm{~mm}$ long. Flowers: pedicel plus ovary ca. $3.8 \mathrm{~mm}$ long, basal node $1.0-1.5$ 


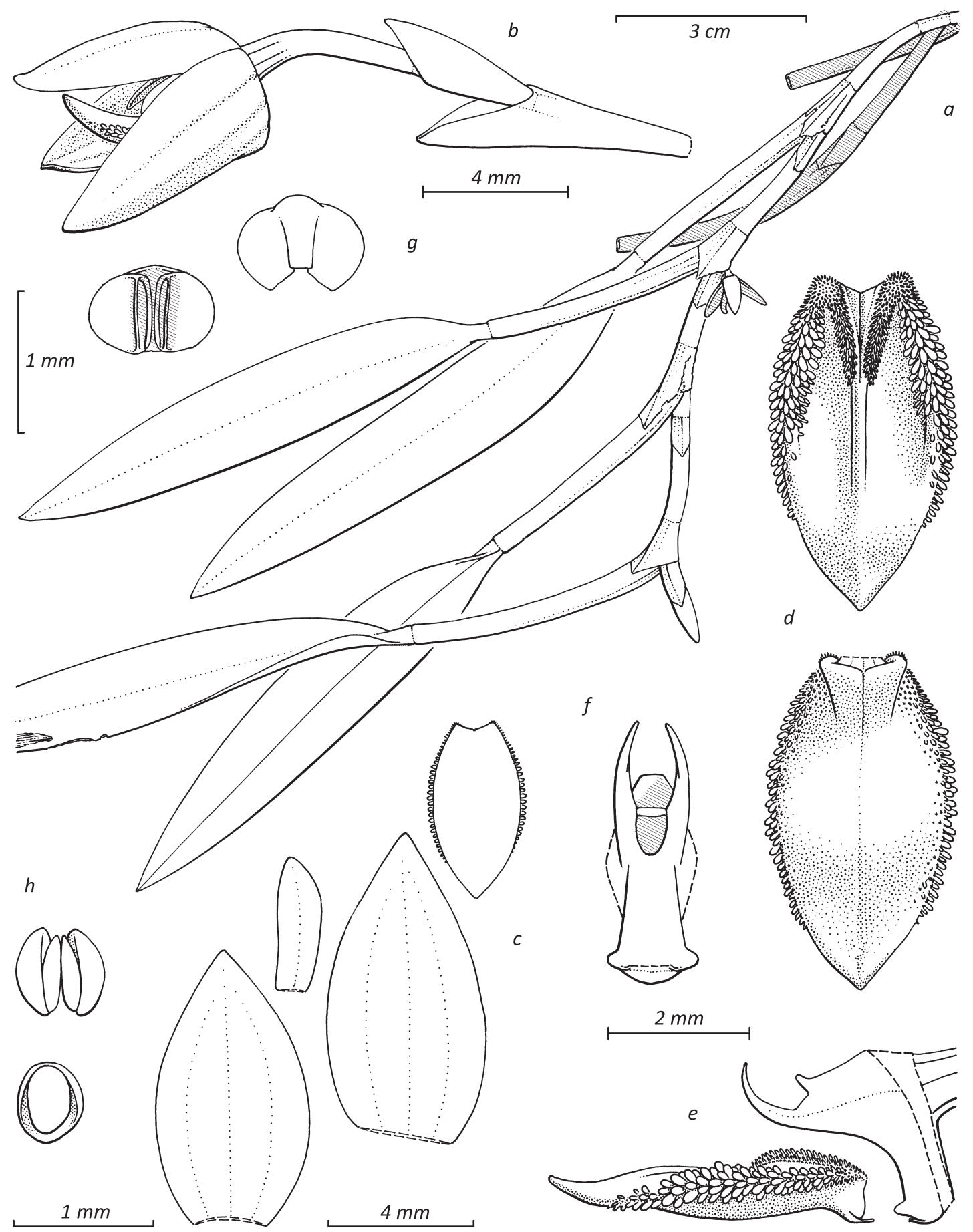

FIgURE 15. Bulbophyllum nudicaule J.J.Verm., Schuit. \& de Vogel. a. Habit. b. inflorescence. c. Flower analysis, from left to right: median sepal, petal, lateral sepal, lip. d. Lip, above: adaxial side, below: abaxial side. e. Column and lip, lateral view. f. Column, frontal view. g. Anther, left: adaxial side, right: abaxial side. h. Pollinia, above: two pairs, below: one pair. Drawn from Carr 10263 by (C) J.J. Vermeulen, from herbarium material. 

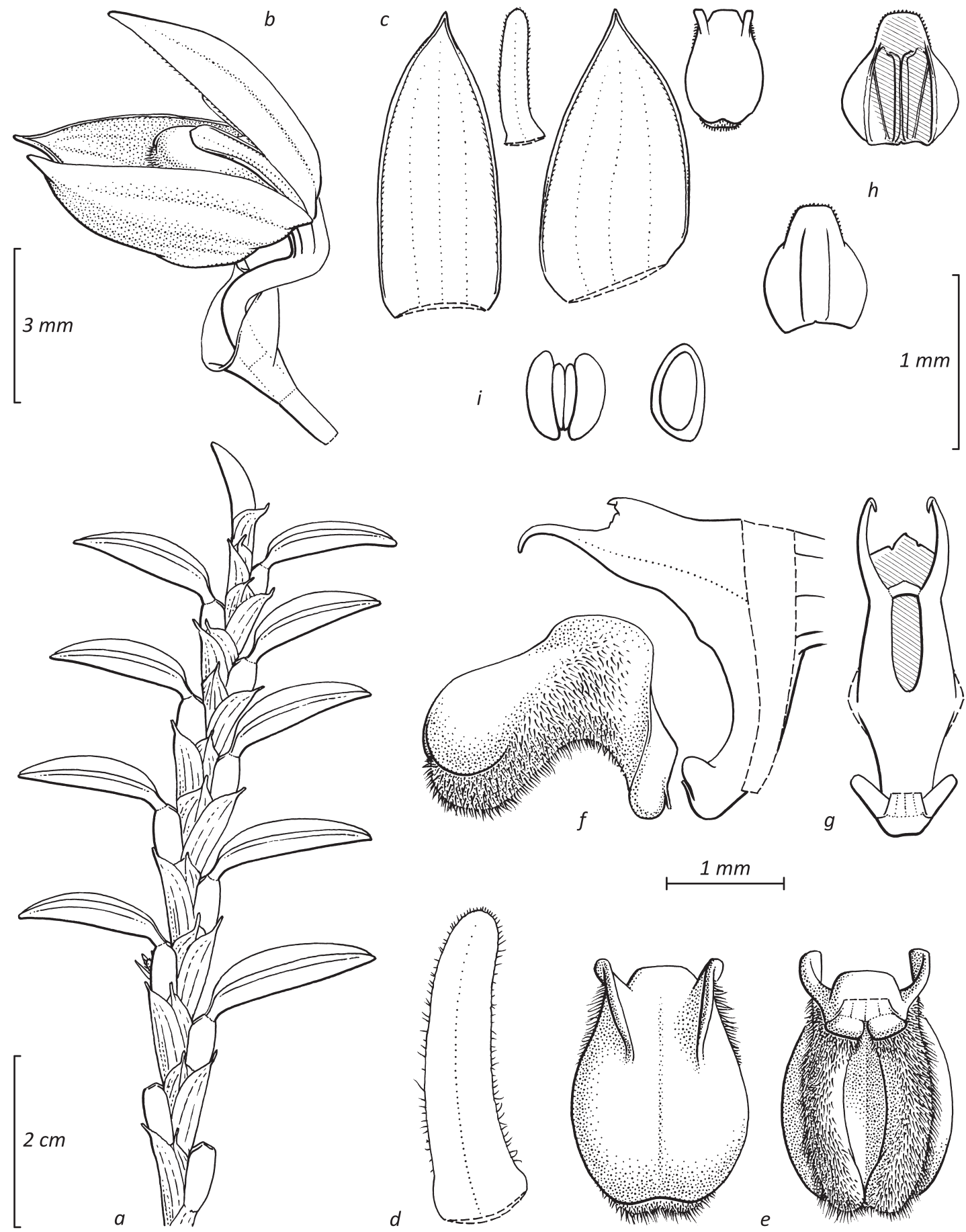

FIgure 16. Bulbophyllum radula J.J.Verm., Schuit. \& de Vogel. a. Habit. b. Flower. c. Flower analysis, from left to right: median sepal, petal, lateral sepal, lip. d. Petal. e. Lip, left: adaxial side, right: abaxial side. f. Column and lip, lateral view. g. Column, frontal view. h. Anther, above: adaxial side, below: abaxial side. i. Pollinia, left: two pairs, right: one pair. Drawn from Reeve 762 by (C) J.J. Vermeulen, from herbarium material. 
$\mathrm{mm}$ above the floral bract attachment. Median sepal free, recurved, ovate-triangular, 4.8-6.0 × 1.8-2.3 $\mathrm{mm}$, ratio length/width 2.2-2.8; acuminate, margins entire, ciliolate, surface glabrous; 3-veined. Lateral sepals as the median but $4.3-5.6 \times 2.3-2.9 \mathrm{~mm}$, ratio length/width 1.8-2.0. Petals porrect, (ovate-)oblong, $2.5-2.7 \times 0.6-0.8 \mathrm{~mm}$, ratio length/width $3.2-4.2$; rounded, margins entire, ciliate, surface glabrous; 1-veined. Lip recurved in the basal half, obovate, 1.9$2.4 \times 1.1-1.6 \mathrm{~mm}$, ratio length/width $1.5-1.8$ (without spreading); rounded, margins entire, glabrous; very thick; adaxially concave proximally with a transverse, rounded callus just above the ligament, with two thin, narrow ridges which start near the base, close to the margin, then converge slightly over the adaxial surface up to approx. half-way the length of the lip, where they merge with the distinctly convex distal part of the lip, adaxial surface glabrous; abaxially with two distinct, rounded, hirsute ridges which are adjacent proximally and distally, distant and with a deep furrow in between elsewhere. Column including stelidia $1.6-2.1 \mathrm{~mm}$ long, stigma narrowly elliptic with slightly protruding base, foot distally with spreading, rounded lateral teeth. Stelidia downwards falcate, narrowly triangular, subulate distally, 0.8-1.2 mm long, acute. Pollinia 4, the inner more than half as long as the outer.

CoLours: tepals proximally white, sepals distally finely spotted brown-purple, petals distally purple. Labellum shiny purple.

Eтyмоlogy: radula (Latin, a noun in apposition) $=\mathrm{a}$ grater, referring to the general shape of the plant.

Habitat AND ECOLOgy: epiphyte, no further details. Elevation $2400 \mathrm{~m}$.

Bulbophyllum squamiplectum J.J.Verm., Schuit. \& de Vogel, sp. nov. (Fig. 17)

TYPE: Indonesia, Papua Province, Wamena, Lake Habbema, $2800 \mathrm{~m}$ alt., Oct. 1938, Brass 10794 (holotype L!).

Diagnosis. Characterized within series $\mathrm{C}$ by the glandular-papillose patch along the median line on the adaxial side of the lip. Bulbophyllum radula has a similar general habit but has an adaxially glabrous lip.

Medium-sized epiphyte with patent to pendulous, sparsely branched rhizomes to $30 \mathrm{~cm}$ long, over which the roots grow towards its base. Rhizome $1.4-3.0 \mathrm{~mm}$ diam., sections between pseudobulbs $0.4-0.8 \mathrm{~cm}$ long, arising from the basal node of the pseudobulb; rhizome scales thin, rather persistent. Pseudobulbs distinct, ellipsoid(-rectangular) to (ob-)ovoid(-rectangular), $0.7-1.5 \times 0.4-0.7 \mathrm{~cm}, 3$-angular, deeply concave on the side where the new shoot arises. Leaf: petiole 1.8$2.5 \mathrm{~mm}$ long; blade probably somewhat succulent but dorsoventrally flattened, elliptic to ovate, $16-32 \times 6-15$ $\mathrm{mm}$, ratio length/width 1.7-4.2; acute. Inflorescences clustered from the basal node of the pseudobulbs, 1-2 cm long, 1-flowered. Peduncle 3-6 mm long, scales 1. Floral bracts ca. $3.8 \mathrm{~mm}$ long. Flowers: pedicel plus ovary ca. $3.0 \mathrm{~mm}$ long, basal node ca. $1.5 \mathrm{~mm}$ above the floral bract attachment. Median sepal free, recurved, ovate, $5.8-8.2 \times 1.7-2.2 \mathrm{~mm}$, ratio length/ width 3.2-3.8; acuminate, margins entire; glabrous, 3 -veined. Lateral sepals as the median but ovatetriangular, 7.8-8.0 × 1.9-2.4 mm, ratio length/width 3.3-4.2. Petals porrect, elliptic to ovate, $1.6-2.1 \times 1.1-$ $1.3 \mathrm{~mm}$, ratio length/width $1.4-1.7$; obtuse to acute, margins entire, ciliate, surface glabrous; 1-veined. Lip slightly recurved, oblong, $1.8-2.0 \times 0.9-1.2$ $\mathrm{mm}$, ratio length/width 1.6-2.2 (without spreading); truncate, margins entire; very thick; adaxially concave proximally, with two narrow ridges which start near the base, close to the margin, then converge slightly over the adaxial surface up to approx. half-way the length of the lip, distal part of the lip slightly concave, with a wide glandular-papillose patch along the median line, towards the base this patch divides into two, lining the inner surface of the ridges, adaxial surface otherwise glabrous; abaxially convex, only slightly furrowed along the median line, surface glabrous. Column including stelidia 1.0-1.2 mm long, stigma obovate, foot distally widened, triangular. Stelidia upwards falcate, triangular, ca. $0.6 \mathrm{~mm}$ long, acute. Pollinia 4 , the inner more than half as long as the outer.

Colours: sepals purple, white towards the margins.

Etymology: squama $($ Latin) $=$ a scale, plecta $($ Latin) a braid, referring to the overlapping pattern of pseudobulbs and leaves.

Habitat And ECOlOgy: sub-pendent epiphyte tufted on branches of a tall tree. Elevation $2800 \mathrm{~m}$. 


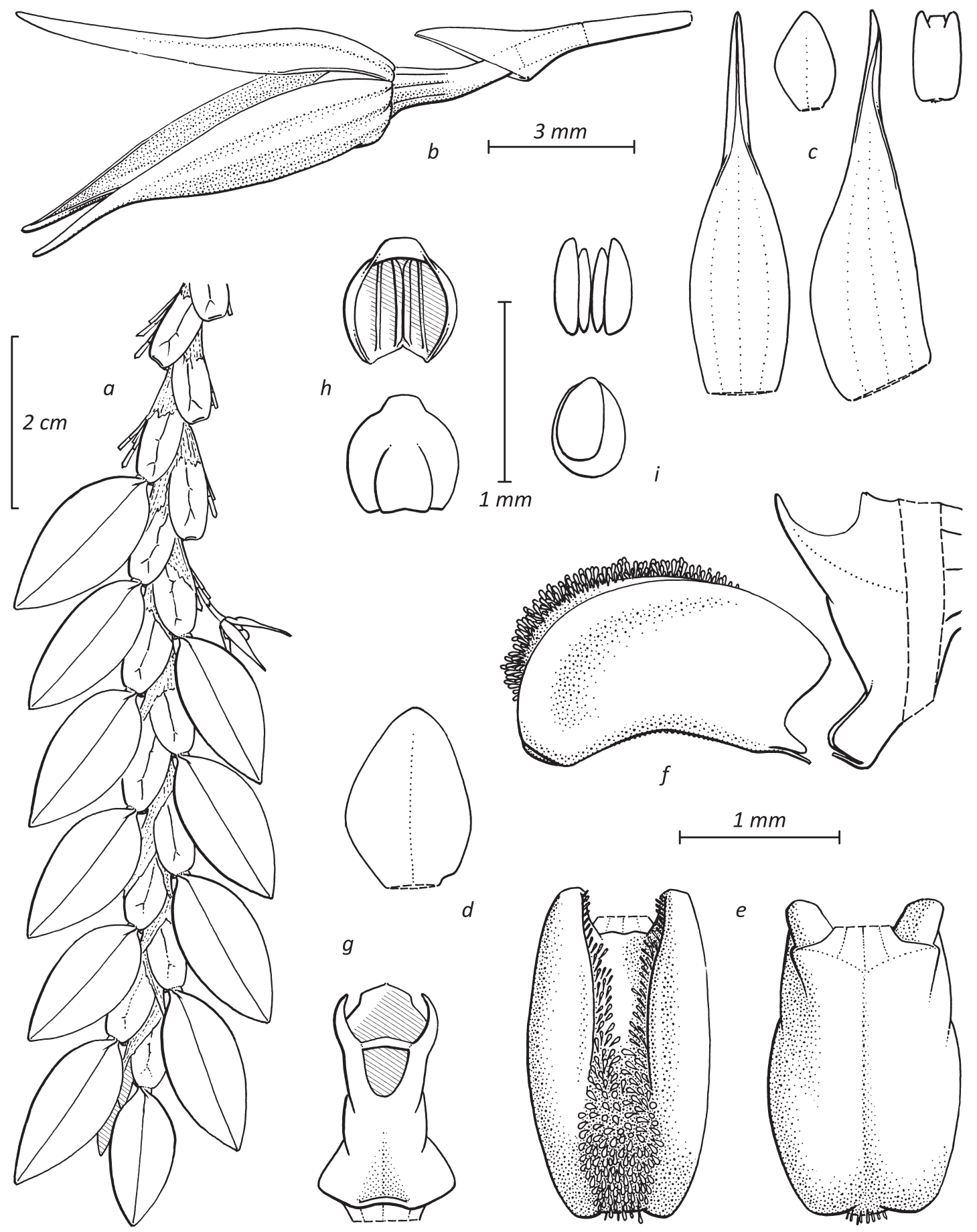

Figure 17. Bulbophyllum squamiplectum J.J.Verm., Schuit. \& de Vogel. a. Habit. b. Flower. c. Flower analysis, from left to right: median sepal, petal, lateral sepal, lip. d. Petal. e. Lip, left: adaxial side, right: abaxial side. f. Column and lip, lateral view. g. Column, frontal view. h. Anther, above: adaxial side, below: abaxial side. i. Pollinia, above: two pairs, below: one pair. Drawn from Brass 10794 by (C) J.J. Vermeulen, from herbarium material. 

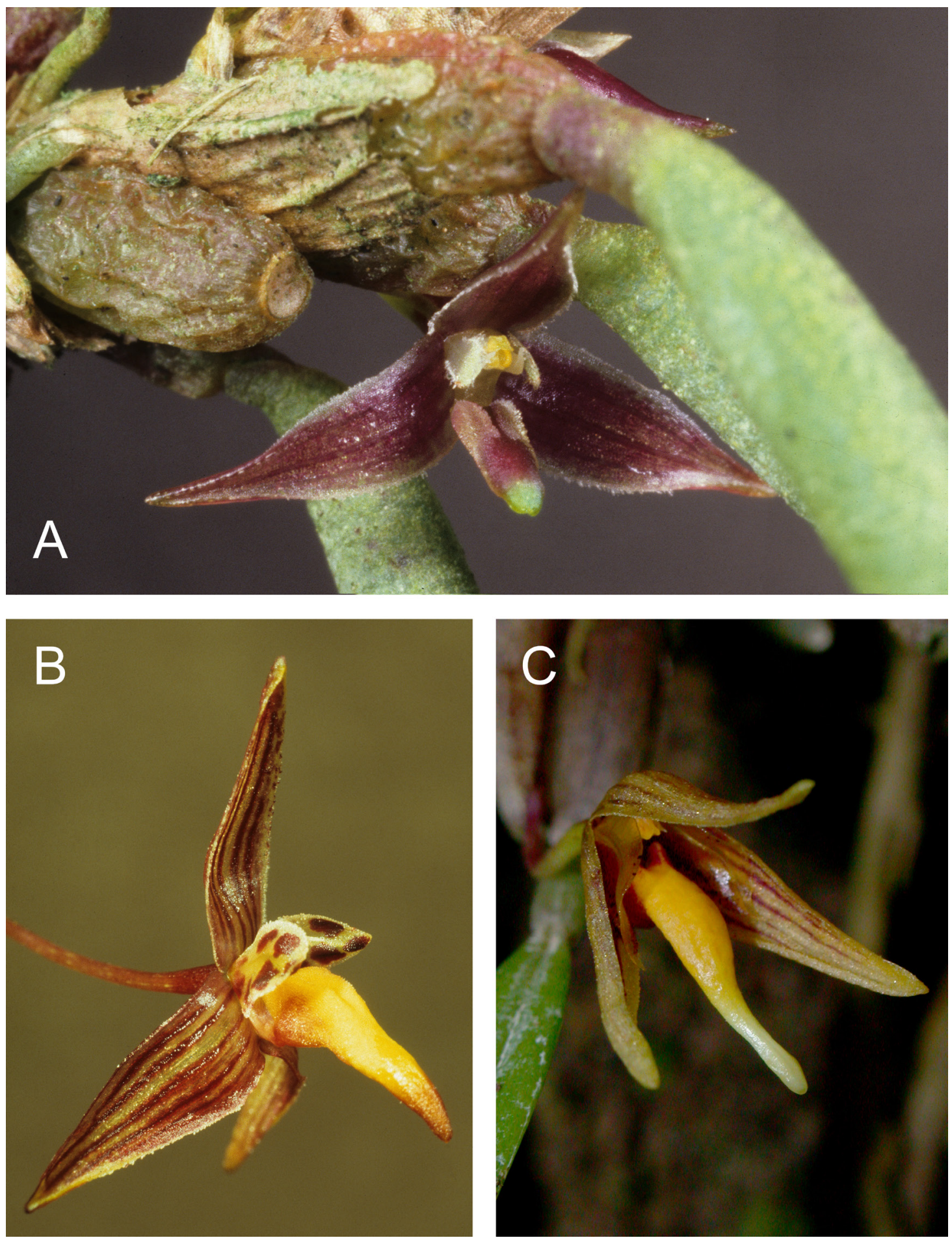

FIgURE 18. New species of Bulbophyllum from New Guinea. A. Bulbophyllum farciminiferum (Jongejan cult. 1700$)$. B. Bulbophyllum nannae (Jongejan cult. 1408); C. Bulbophyllum lipochilum [de Vogel \& Vogel (2002) s.n., L alc. 18379]. Photographs by P. Jongejan (A, B) and E.F. de Vogel (C). 


\section{LITERATURE CITED}

Schuiteman A, Vermeulen, J. J. \& de Vogel, E. F. (2010). Flora Malesiana: Orchids of New Guinea Vol. VI. Genus Bulbophyllum (CD-ROM). Amsterdam/Leiden: ETI/Nationaal Herbarium Nederland. Also available at http://www. orchidsnewguinea.com

Vermeulen J. J., Fischer, G., de Camargo Smidt, E., Stern, W. L., Pridgeon, A. M., Veitch, C., Sieder, A., Vugt, R. van \& Gravendeel, B. (2014). Bulbophyllum. In: A. M. Pridgeon,P. J. Cribb, M. W. Chase, \& F. N. Rasmussen (Eds.), Genera Orchidacearum Vol. 6, Epidendroideae pt. 3 (pp. 4-51). Oxford, UK: Oxford University Press. 